\title{
U.S. RADIOECOLOGY RESEARCH PROGRAMS OF THE ATOMIC ENERGY COMMISSION IN THE 1950s
}

December 2003

D. E. Reichle and S. I. Auerbach

Environmental Sciences Division

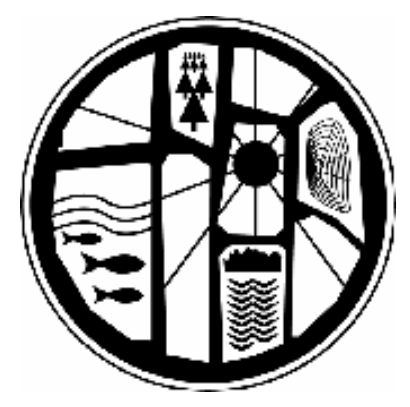




\section{DOCUMENT AVAILABILITY}

Reports produced after January 1, 1996, are generally available free via the U.S. Department of Energy (DOE) Information Bridge.

Web site http://www.osti.gov/bridge

Reports produced before January 1, 1996, may be purchased by members of the public from the following source.

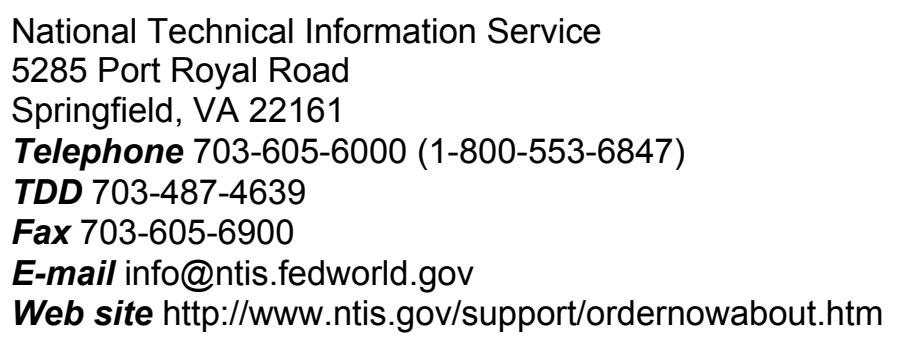

Reports are available to DOE employees, DOE contractors, Energy Technology Data Exchange (ETDE) representatives, and International Nuclear Information System (INIS) representatives from the following source.

Office of Scientific and Technical Information

P.O. Box 62

Oak Ridge, TN 37831

Telephone 865-576-8401

Fax 865-576-5728

E-mail reports@adonis.osti.gov

Web site http://www.osti.gov/contact.html

This report was prepared as an account of work sponsored by an agency of the United States Government. Neither the United States Government nor any agency thereof, nor any of their employees, makes any warranty, express or implied, or assumes any legal liability or responsibility for the accuracy, completeness, or usefulness of any information, apparatus, product, or process disclosed, or represents that its use would not infringe privately owned rights. Reference herein to any specific commercial product, process, or service by trade name, trademark, manufacturer, or otherwise, does not necessarily constitute or imply its endorsement, recommendation, or favoring by the United States Government or any agency thereof. The views and opinions of authors expressed herein do not necessarily state or reflect those of the United States Government or any agency thereof. 
ORNL/TM-2003/280

Environmental Sciences Division

\title{
U.S. RADIOECOLOGY RESEARCH PROGRAMS OF THE ATOMIC ENERGY COMMISSION IN THE 1950s
}

\author{
D. E. Reichle ${ }^{1}$ and S. I. Auerbach ${ }^{2}$ \\ Environmental Sciences Division \\ Oak Ridge National Laboratory
}

\footnotetext{
${ }^{1}$ Former Associate Laboratory Director, Life Sciences and Environmental Technologies, ORNL

${ }^{2}$ Retired Founding Director, Environmental Sciences Division, ORNL
}

Date Published: December 2003

Prepared for the

Environmental Sciences Division

Office of Biological and Environmental Research

U.S. Department of Energy

Budget Activity Number KP 1204010

Prepared by

OAK RIDGE NATIONAL LABORATORY

Oak Ridge, Tennessee 37831

managed by

UT-BATTELLE, LLC

for the

U.S. DEPARTMENT OF ENERGY

under contract DE-AC05-00OR22725 



\section{CONTENTS}

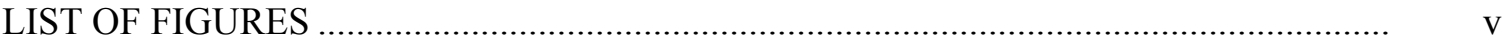

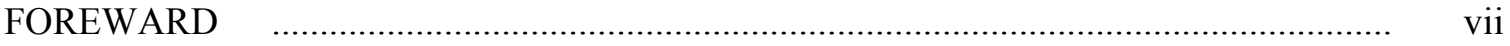

1. U.S. RADIOECOLOGY RESEARCH PROGRAMS INITIATED IN THE 1950s ........ 1

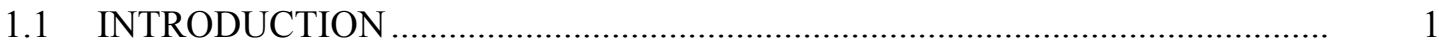

1.2 THE BEGINNING OF THE RADIOECOLOGY RESEARCH PROGRAMS ..... 1

1.3 THE ECOLOGICAL ISSUES ............................................................................ 3

1.4 THE EARLY RADIOECOLOGY PROGRAMS ....................................................

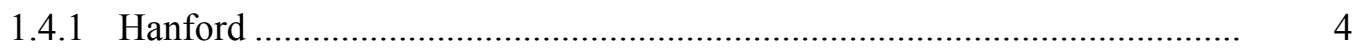

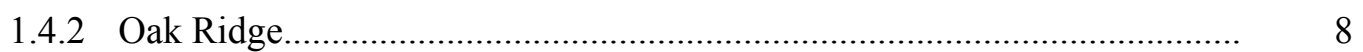

1.4.3 Savannah River ................................................................................... 18

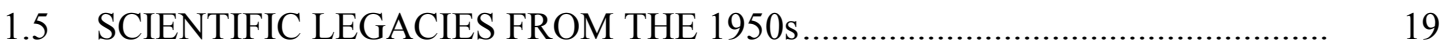

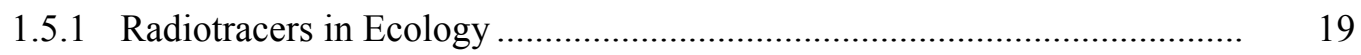

1.5.2 Food Chain Dynamics .............................................................................. 19

1.5.3 Environmental Protection....................................................................... 21

1.5.4 Regulations and Science ...................................................................... 21

1.5.5 The Dynamic Nature of Ecosystems Revealed ........................................ 21

1.5.6 The Unfulfilled Promise............................................................................. 22

2. U.S. ATOMIC ENERGY COMMISSION'S ENVIRONMENTAL RESEARCH

PROGRAMS ESTABLISHED IN THE 1950s .......................................................... 23

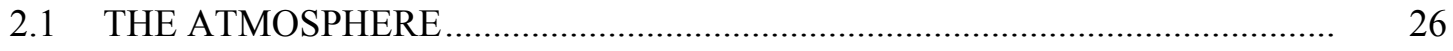

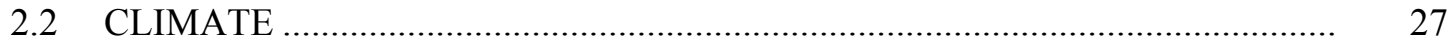

2.3 THE DYNAMIC OCEAN ............................................................................... 28

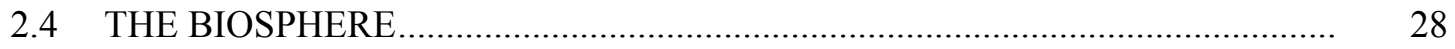

2.5 THE LEGACY OF THE 1950s ……………................................................. 32

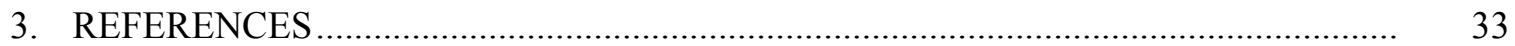





\section{LIST OF FIGURES}

Figure

1.1 Fisheries Laboratory at the Hanford Site as it appeared during the 1950s (courtesy of Pacific Northwest National Laboratory)

1.2 Production process creating plutonium and radioactive wastes at Hanford (from Bustad 1960).

1.3 Staff of the Ecology Laboratory at Oak Ridge National Laboratory in 1956 (the laboratory was housed at the Y-12 Plant from 1955 to 1961).

1.4 Aerial photograph of drained White Oak Lake bed in 1955.

1.5 Naturally revegetated White Oak Lake bed in 1958, where early radioecological studies were conducted.

1.6 Radionuclide concentrations in soils and plants on White Oak Lake bed in 1957.

1.7 Transfer of radionuclides from plants to insects on White Oak Lake bed: (top half) cesium-137 and (bottom half) strontium-90.

1.8 Distribution of strontium-90 (upper value) and cesium-137 (lower value) in soil and biota at White Oak Lake bed

1.9 Radiotracer studies of food chains at the Savannah River Site. The concentration of phosphorus-3 was measured in six animal populations in Quadrat 2, where Rumex was the main vegetation.

2.1 Seven DOE National Environmental Research Parks, which represent major ecosystems covering more than half of the lower 48 states. 


\section{FOREWORD}

This report contains two companion papers about radiological and environmental research that developed out of efforts of the Atomic Energy Commission in the late 1940s and the 1950s. Both papers were written for the Joint U.S.-Russian International Symposium entitled "History of Atomic Energy Projects in the 1950s-Sociopolitical, Environmental, and Engineering Lessons Learned," which was hosted by the International Institute for Applied Systems Analysis in Laxemberg, Austria, in October 1999. Because the proceedings of this symposium were not published, these valuable historic reviews and their references are being documented as a single ORNL report.

The first paper, "U.S. Radioecology Research Programs Initiated in the 1950s," written by David Reichle and Stanley Auerbach, deals with the formation of the early radioecological research programs at the U.S. Atomic Energy Commission's nuclear production facilities at the Clinton Engineering Works in Oak Ridge, Tennessee; at the Hanford Plant in Richland, Washington; and at the Savannah River Plant in Georgia. These early radioecology programs were outgrowths of the environmental monitoring programs at each site and eventually developed into the world renowned National Laboratory environmental program sponsored by the Office of Biological and Environmental Research of the U.S. Department of Energy. The original version of the first paper was presented by David Reichle at the symposium.

The second paper, "U.S. Atomic Energy Commission's Environmental Research Programs Established in the 1950s," summarizes all the environmental research programs supported by the U.S. Atomic Energy Commission in the 1950s and discusses their present-day legacies. This paper is a modified, expanded version of a paper that was published in September 1997 in a volume commemorating the 50th anniversary symposium of the U.S. Department of Energy's Office of Biological and Environmental Research (DOE/BER). Contributors to the original work-Murray Schulman, DOE Headquarters, retired; Jerry Elwood, DOE/BER; David Reichle, Oak Ridge National Laboratory; and Ward Wicker, Colorado State University-provided further insight into environmental research in the decade of the 1950s and expanded the environmental part of the original document. The original version of the second paper was presented by David Reichle in poster session at the symposium. 


\section{U.S. RADIOECOLOGY RESEARCH PROGRAMS INITIATED IN THE 1950s}

\subsection{INTRODUCTION}

In the early postwar years, beginning in 1949 and extending to the mid-1960s, U.S. Atomic Energy Commission (AEC) research on the fate and effects of radionuclides in the environment was driven by distinct environmental concerns - the releases of radioactive materials around production sites, fallout from nuclear weapons tests, and radiation effects from both external and internal exposures. These problem areas spawned development of the scientific field of radioecology. To understand the perspectives of the United States in the 1950s on the issues of nuclear energy and the environment, we have reviewed the early research programs. Keeping to the theme of the papers in this environmental session, we will focus on the first area of concern - the scientific studies aimed at understanding the environmental consequences of nuclear production and fuel reprocessing at the three primary production sites: the Hanford Works in the state of Washington; the Clinton Laboratories in Oak Ridge, Tennessee; and the Savannah River Plant in South Carolina. The driving environmental issue was the fate and effects of waste products from nuclear fuel production and reprocessing - that is, concern about their entry into environmental pathways. Early operational monitoring and evaluation by health physicists led to the realization that additional emphasis needed to be placed on understanding the environmental fate of radionuclides. In turn, this realization led to forward-thinking research and development $(\mathrm{R} \& \mathrm{D})$ planning and the development of interdisciplinary research teams for experimentation on complex environmental systems. This paper presents a review of the major AEC radioecology research programs initiated during the 1950s, the issues leading to the establishment of these programs, their early results, and their legacies for environmental protection and ecological research in the decades that followed.

\subsection{THE BEGINNING OF THE RADIOECOLOGY RESEARCH PROGRAMS}

At the beginning of the 1950s, there was increased awareness of the need for research dealing with the broader aspects of nuclear energy and the problems associated with the production and testing of nuclear bombs. Small environmental programs were established at a number of AEC facilities that produced materials and components for bombs. These programs were concerned with the possible problems associated with releases to the local environments (Stannard 1988). For example, at the Hanford Atomic Works in the state of Washington, an aquatic biology testing facility was established to monitor and assess the possible impact of radionuclides that were being discharged to the Columbia River in water that cooled the giant reactors used in the production of plutonium (Foster 1972). There the scientists evaluated the uptake of nuclides, particularly phosphorus-32 and zinc- $65\left({ }^{65} \mathrm{Zn}\right)$, in the Columbia River fish populations, as well as other edible marine species such as oysters, clams, and crustaceans in the ocean waters off the mouth of the Columbia River (Foster and Davis 1956).

Another giant nuclear production facility was built and put into operation in South Carolina in the 1950s (Odum 1956). There the AEC, already sensitive to the need for 
environmental surveillance, contracted with the University of Georgia to carry out preoperational surveys. This project was led by Eugene Odum, already a prominent American ecologist. In this case, the Georgia scientists, not yet knowledgeable about radionuclides and their environmental problems, focused on developing background information that would prove useful in understanding possible ecosystem consequences in the vicinity of the facility.

Meanwhile Oak Ridge National Laboratory (ORNL) became a center for development of reactor fuel element reprocessing technology. Reprocessing of fuel elements was necessary to recover the unburned fissile materials, primarily plutonium and uranium-235, which could be reused. At the same time, this process resulted in the extraction of waste fission products left from the fission reaction. Some of the many species of radionuclides, because of their long half-lives or their abundance, were recognized as requiring subsequent treatment and disposal in ways that would minimize their release to the environment. Among these elements were strontium-90 $\left({ }^{90} \mathrm{Sr}\right)$, cesium-137 $\left({ }^{137} \mathrm{Cs}\right)$, cobalt-60 $\left({ }^{60} \mathrm{Co}\right),{ }^{65} \mathrm{Zn}$, and ruthenium-106. Those with the longest half-lives were of most concern, such as ${ }^{90} \mathrm{Sr}$, ${ }^{137} \mathrm{Cs}$, and ${ }^{60} \mathrm{Co}$ (Auerbach 1993; Whicker and Schultz 1982).

In the 1950s, two methods were used for the disposal of radioactive waste. The large quantities of high-level wastes were stored in specially designed underground tank systems. The wastes containing lesser quantities of radionuclides were, especially at ORNL, either released slowly to a nearby stream after treatment and dilution or placed in large earthen pits (either open or below ground) and allowed to seep into the nearby soil. This second method was predicated on the assumption that the various nuclides would be chemically retained in the surrounding soil column as a result of the chemical fixation of the nuclide species within the exchange complex of the surrounding soil mass. Laboratory studies had shown that these soils had a strong chemical affinity for some of the nuclides, especially ${ }^{137} \mathrm{Cs}$.

Weapons testing was being conducted in the United States and elsewhere, and a number of countries were becoming concerned about worldwide fallout, particularly fallout of ${ }^{90} \mathrm{Sr}$. Results of surveys of contaminated biota on contaminated islands in the Pacific Proving Grounds were first published in 1956 (AEC 1956). Meanwhile, agricultural scientists in the United States and Great Britain began investigations and field studies on the factors governing the uptake of ${ }^{90} \mathrm{Sr}$ and its transport into food chains that led directly to man, especially through milk as well as into major food crops (Klement 1965). In these countries this research was supported by the respective energy agencies and carried out in the major agricultural research stations (e.g., Beltsville, U.S.A.; Agricultural Research Council, U.K.).

There was also an established network for monitoring and measuring the radioactive fallout from the testing of atomic bombs that had continued into the 1950s. The AEC had a broad network of monitoring stations across the United States (Eisenbud and Harley 1953). This program mainly focused on measuring the species and quantities of radionuclides deposited across the country, and it developed a continuing accounting of the quantities of radionuclides - ${ }^{90} \mathrm{Sr},{ }^{137} \mathrm{Cs}$, and ${ }^{131} \mathrm{I},{ }^{60} \mathrm{Co}$, and others - that were the fission by-products of nuclear bomb testing.

Awareness of potential and growing ecological problems associated with atomic energy operations and programs began to develop in the 1950s. Perceptive research scientists and 
health physicists started to worry about the consequences of large-scale radioactive waste disposal activities at atomic energy facilities, especially ORNL (Browder 1959; ORNL 1957). At this laboratory they were already experiencing seepage of wastes from disposal areas into streams and ultimately into the nearby Clinch River. Moreover, they were aware that similar phenomena were occurring at other AEC facilities. They became concerned about the entry of radionuclides into ecological food chains and the subsequent fate and potential impacts on man through his food stuffs, as well as concerned about the effect on the ecology of the landscape.

The combination of airborne releases from worldwide weapons testing and the potential larger scale local releases of radioisotopes from atomic energy research and production facilities resulted in a major concern about the threat, not only to man, but also to the various ecological food chains, populations, and ecosystems that compromise what we recognize as the Earth's biosphere. These concerns were recognized to various degrees in the several countries that were then actively engaged in atomic energy development - both for military and peaceful purposes. Health physicists, biologists, and a small number of ecologists quickly realized there was a commonality of issues that would require unprecedented research. In the broad sense, the concerns were ecological, although research soon encompassed most aspects of what we now recognize as environmental science.

\subsection{THE ECOLOGICAL ISSUES}

Throughout the late 1940s and 1950s, the recurrent themes associated with radioactive contamination dealt with various aspects of environmental transport that were fundamental to understanding both human and environmental health consequences of nuclear energy. The problems of environmental transport involve scores of variables. Research in the field consequently involved aerosol physicists, meteorologists, hydrologists, ecologists, agronomists, oceanographers, soil scientists, and geologists who studied complex environmental systems. Specialists focused on the somewhat distinct components of environmental systems:

- atmospheric transport and disposition,

- terrestrial uptake and transport,

- surface water transport, and

- groundwater movement.

They were concerned mainly with tritium and the radioactive isotopes of strontium, cesium, ruthenium, cobalt, iodine, plutonium, and transuranics (uranium and thorium).

Atmospheric dispersion and diffusion studies addressed both meteorology and topography in estimating deposition and interception of isotopes by vegetation, soils, and surface waters. Terrestrial transport studies included soils, vegetation, animal components, and organisms as both transporters and recipients. Surface water studies included rivers, lakes, and oceans receiving input from atmospheric input, land runoff, or groundwater seepage, and they encompassed water chemistry and the aquatic ecological systems (see Parker, in these proceedings). Groundwater movement of radionuclides was closely linked to subsurface burial and ground disposal in seepage pits of radioactive wastes (S. Stow, Oak Ridge National Laboratory, personal communication). 
Critical pathways for the movement of radionuclides in the environment had to be determined before more sophisticated experiments on isotope bioavailability and environmental mobility could be conducted. Transfer coefficients for various radionuclides were important for determining ecological fate as well as potential ingestion exposures to man; furthermore, it required detailed information on environmental chemistry, biochemistry, and physiology. Much of this information became incorporated into simulation models that were developed in the following decades to evaluate the hazards of environmental contamination from nuclear facilities (Parker 1956), weapons testing (Tamplin 1967), or peaceful applications of nuclear energy (Kaye et al. 1972). Enormous efforts of federal and private agencies in surveillance networks for measuring fallout in the environment were fundamental to all these applied studies.

Very early in the development of radioecology, it became apparent that cycling and recycling of radionuclides were unique characteristics of ecological systems and that both influenced the ultimate behavior of radionuclides in the environment. Auerbach (1965) described how the recycling phenomenon had focused radioecologists into four lines of investigation: (1) the movement of radionuclides across different trophic levels, (2) linkages in food chains between trophic levels, (3) turnover of radionuclides by different trophic levels, and (4) complete cycles of radionuclides in different ecosystems. These were research topics for radioecologists, who used contaminated environments and experimental tagging with radioisotopes to tease out evidence of the complicated interrelationships.

\subsection{THE EARLY RADIOECOLOGY PROGRAMS}

\subsubsection{Hanford}

Stafford Warren, medical director of the Manhattan Engineer District, raised questions about the impacts of the Plutonium Project on the Columbia River only a few months after the decision to locate the project at Hanford. In the same year that construction began (in 1943), a contract was let to the Applied Fisheries Laboratory of the University of Washington in Seattle to study the effects of X-rays on the development of salmon and later, trout. Early research was interrupted by the immediate need to understand the fate and effects of the Hanford pile effluents (Stannard 1988) and Richard Foster was recruited to Hanford from Seattle to begin work at the site out of the Fisheries Laboratory (Fig. 1.1).

This research group working on the Columbia River and in the northern cold desert of the Great Basin proceeded to investigate two problem areas: (1) exposure of fingerlings to various concentrations of pile effluents and possible biological effects and (2) uptake and retention of pile effluents. The plant operation and environmental interactions are illustrated in Figure 1.2. By 1946, studies had shown that the fisheries resources of the Columbia River were not threatened by the plutonium plant and that there was no radiation hazard either to the people who used the river or to the fish (Foster 1972). In fact, process chemicals in the reactor effluent (sodium dichromate) showed greater potential toxicity to aquatic life than the radionuclides discharged and ultimately proved to be the principal toxic hazard to aquatic life.

At the First International Conference on the Peaceful Uses of Atomic Energy, held in Geneva in 1955, Foster and Davis (1956) summarized the work on aquatic life. 


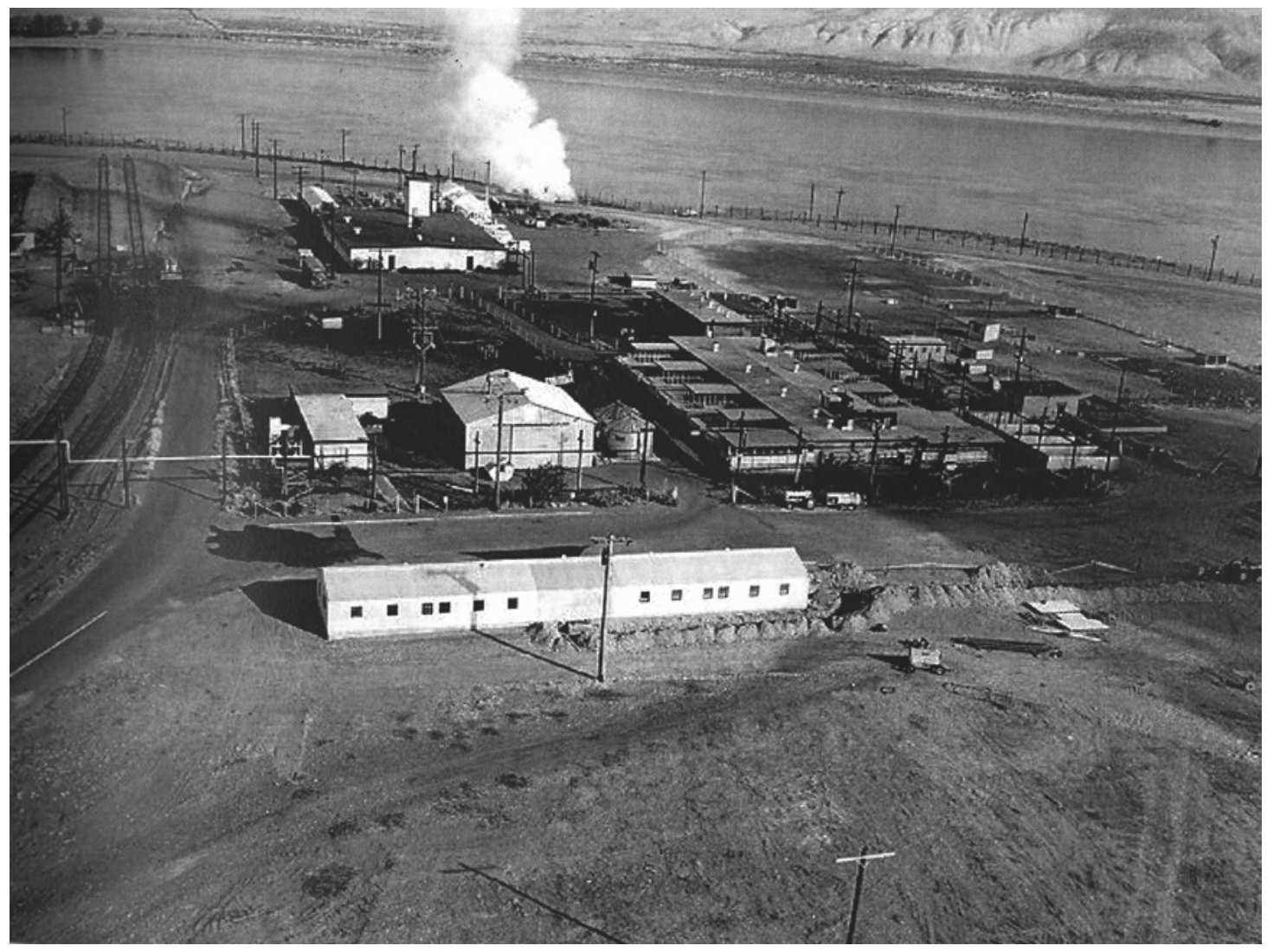

Fig. 1.1 Fisheries Laboratory at the Hanford Site as it appeared during the 1950s (courtesy of Pacific Northwest National Laboratory). 
ORNL 99-05752A/trh

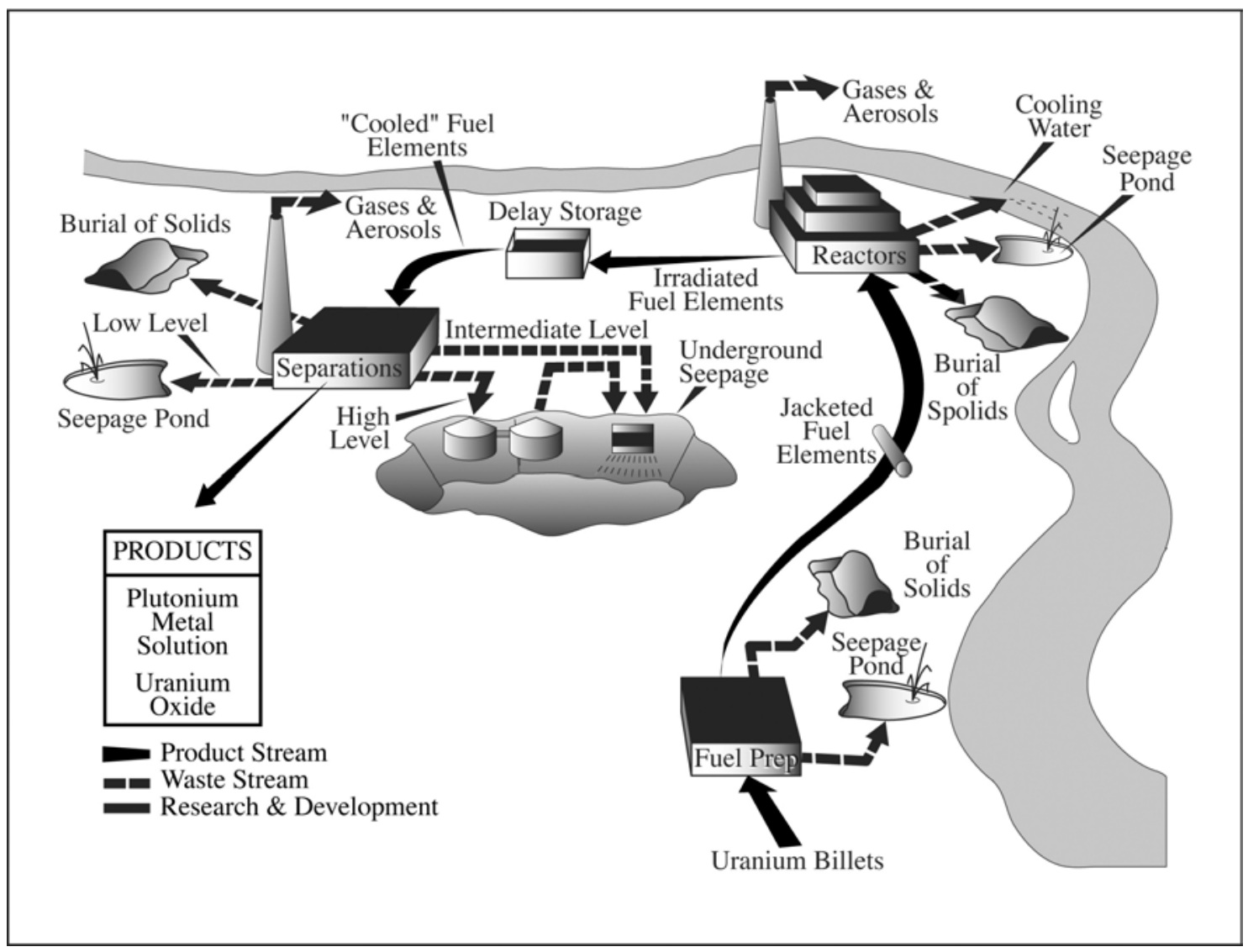

Fig. 1.2. Production process creating plutonium and radioactive wastes at Hanford (from Bustad 1960). 
Radioactivity ("radioactivity density") was found to vary by an order of magnitude in plankton versus fish. Aquatic plants adsorbed significant quantities of radioactive materials on their surfaces. The scales of fish contained the highest concentrations, followed by bone, liver, and kidney - similar to patterns of contamination in terrestrial organisms. Furthermore, radioactivity concentrations in plankton, snail, and other aquatic organisms decreased rapidly down river from the Hanford plant. Some other unexpected ecological findings (Foster 1979) came to light, such as the importance of the food chain accumulation of radionuclides and the importance of understanding the long-term behavior of radionuclides in aquatic environments.

An Unexpected Source of Radioactivity. As the techniques for identifying and separating radioisotopes became more routine, it became apparent that the radioisotopes in the river were largely products of neutron activation of substances already present in the river water and pile components, including natural uranium in the river water.

The Importance of Background Radioactivity. A surprise finding was that the radioactivity in fish from the river was substantially higher than that predicted from laboratory exposures to pile effluents. This finding was explained by the fact that laboratory fish were fed uncontaminated food whereas fish in the river were eating food that contained natural radioactivity (in amounts of greater significance than reactor discharges). This finding revealed the importance of the food chain and metabolic processes in determining whole-body concentrations.

The Significance of the Food Chain. Another surprise finding was the qualitative differences in the elemental composition of radioactivity in laboratory fish versus river fish. The radioactive body burdens of laboratory fish came from elements such as sodium and other short-lived isotopes that were easily assimilated from the water. In contrast, fish from the river exhibited high concentrations of isotopes such as ${ }^{32} \mathrm{P}$, which had been concentrated from food resources. Again, the importance of metabolic processes in concentrating some radioisotopes from the environment and the importance of the food chain were demonstrated.

A sizable program in terrestrial ecology was also under way at Hanford, observed under the broad title of "Biological Monitoring." At the First International Conference on the Peaceful Uses of Atomic Energy, Hanson and Kornberg (1956) showed concentrations and ratios of ${ }^{32} \mathrm{P}$ in adults, eggs, and young birds in relation to the amount in water, with no effect on adult fertility or egg hatchability. They measured the isotopic concentration of swamp water, vegetation, and bird muscle and bone. They reported that ${ }^{131}$ I concentration factors that could range from 0.2 in vegetation (the food staple) to 1 in insects, 100 in rabbits, and 20 in coyotes. Leo Bustad (1960) at a symposium on radioisotopes in the biosphere gave a summary of the Hanford work in relation to animal populations (Table 1). He showed the concentrations of 11 isotopes in fish, the concentration of ${ }^{65} \mathrm{Zn}$ in beef cattle, and rats' accumulation of radioisotopes from drinking water. By the early 1960s, Hanson (1963) had reviewed nearly every aspect of iodine in the environment, illustrating a remarkable process in this area of investigation. 
Table 1. Radioisotopes in tissues of fish from Hanford (after Bustad 1960)

\begin{tabular}{ccc}
\hline Isotope & $\begin{array}{c}\text { Organ or tissue showing } \\
\text { highest concentration }\end{array}$ & $\begin{array}{c}\text { Concentration } \\
(\mu \mathrm{c} / \mathrm{g} \text { wet weight })\end{array}$ \\
\hline${ }^{4} \mathrm{Na}$ & Bone & $2 \times 10^{-3}$ \\
${ }^{6} \mathrm{Sc}$ & Spleen & $2 \times 10^{-6}$ \\
${ }^{2} \mathrm{P}$ & Gut content & $7 \times 10^{-3}$ \\
${ }^{51} \mathrm{Cr}$ & Blood & $5 \times 10^{-4}$ \\
${ }^{54} \mathrm{Mn}$ & Bone & $5 \times 10^{-5}$ \\
${ }^{59} \mathrm{Fe}$ & Gut content & $3 \times 10^{-5}$ \\
${ }^{60} \mathrm{Co}$ & Spleen & $1 \times 10^{-5}$ \\
${ }^{80-90} \mathrm{Sr}$ & Bone & $8 \times 10^{-6}$ \\
${ }^{64} \mathrm{Cu}$ & Gut content & $1 \times 10^{-3}$ \\
${ }^{65} \mathrm{Zn}$ & Retina & $3 \times 10^{-3}$ \\
${ }^{137} \mathrm{Cs}$ & Muscle & $9 \times 10^{-7}$ \\
\hline
\end{tabular}

\subsubsection{Oak Ridge}

During the war years, the Clinton Laboratories had no research program directed at environmental issues other than those associated with plant operations, which included routine industrial hygiene (health physics) practices and measurements of air and waterborne radioactivity. This laboratory was located in Eastern Tennessee, in the Southern mixed hardwood forests of the Ridge and Valley Province of the south central United States. Karl Z. Morgan, director of the Health Physics Division at ORNL (Clinton Laboratories became Oak Ridge National Laboratory in 1948) became increasing concerned about the possible impacts of contamination released to the environment. The laboratory's waste disposal practice during the Manhattan Engineer District years was to conduct treatment and low-level river discharges. Pit and trench disposal started in 1951, using largely unlined impoundments and basins that were not isolated from the environment. Initial ecological work was contracted to L. A. Krumholz and colleagues at the Tennessee Valley Authority, and a program was established in 1950. They could find no evidence of deleterious effects in aquatic or terrestrial populations (Stannard 1988).

These early negative results, plus the horror in the minds of the physicist leaders at the laboratory about the complexity, variability, and resiliency of natural ecosystems, almost doomed the future of scientific ecological research in Oak Ridge (Stannard 1988). Several factors occurred which saved the program: (1) K. Z. Morgan's crusade for continuing the work (Morgan and Peterson 1999), (2) the laboratory's decision to drain the White Oak Lake holding basin in 1955 for low-level wastes (Johnson and Schaffer 1994), and (3) the understanding of Eugene Wigner (former research director of Clinton Laboratories and a future Nobel laureate) that radioactive waste disposal would be a key problem in the development of nuclear power (Stannard 1988). Morgan transferred Ed Struxness, supervisor of health physics at the Oak Ridge Y-12 weapons plant, to ORNL to work on waste management problems. To Struxness this meant research on and in the environment; he soon recruited Orlando Park, professor of Ecology at Northwestern University, and his student, Stanley Auerbach, was hired in 1955 as the first ORNL 
ecologist. Thus the Oak Ridge Ecology Program began with 1.7 man-years and a $\$ 56,000$ budget (Fig. 1.3). The drained White Oak lakebed became the site of Oak Ridge's early experimental ecological research.

The new program was laboratory-based, with objectives to establish dose effect relationships for a broad spectrum of forest insect and other arthropod organisms. Laboratory experiments also included the uptake of fission products, particularly ${ }^{89} \mathrm{Sr}$ and ${ }^{90} \mathrm{Sr}$. Limitations of personnel and funds limited the start of extensive field studies. Early field studies utilized terrestrial microcosms and laboratory experiments to measure the uptake and bioaccumulation of ${ }^{89} \mathrm{Sr}$ by various species of earthworms (Auerbach 1956; Auerbach et al. 1958). In the latter part of 1955, two events changed the direction of the new program. First, the new AEC Environmental Research Branch Manager John Wolfe and his Program Manager Vincent Schultz advised ORNL that the new ecology program should be redirected to a field research effort rather than a laboratory one and that it should be oriented toward radioactive waste disposal and contamination problems in the context of ecological science. Second, the 25-hectare impoundment (White Oak Lake) that had been the final settling basin for released low-level quantities of radioactive waste fission products and other chemicals was drained. This action resulted in a new, highly contaminated terrestrial environment that contained large quantities of ${ }^{90} \mathrm{Sr},{ }^{137} \mathrm{Cs},{ }^{60} \mathrm{Co}$, and other radioisotopes (Figs. 1.4-1.6).

White Oak Lake Bed. Prior to the draining of the lake, large (1,000,000-gallon) open earth pits had been dug on the hillside above the lake bed. These pits were considered experimental disposal sites for radwaste products produced from the reprocessing of used reactor fuel elements. ORNL at that time was the major R\&D center for chemical engineering studies on techniques for reprocessing used reactor fuel elements. The byproducts included large quantities of fission products, which in the several stages of reprocessing were segregated into high-level wastes and large volumes of lower activity wastes containing principally ${ }^{90} \mathrm{Sr},{ }^{137} \mathrm{Cs},{ }^{60} \mathrm{Co}$, and ${ }^{106} \mathrm{Ru}$. The high-level wastes were siphoned to underground storage tanks. The lower activity wastes were sent to experimental earthen pits whose soil properties indicated a high exchange capacity for fixing both ${ }^{90} \mathrm{Sr}$ and ${ }^{137} \mathrm{Cs}$. Ruthenium-106 was found to be mostly non-fixable, and it seeped out of the pits into small drainages that emptied into the White Oak lake bed.

Even by the standards of that time, the White Oak lake bed was considered to be highly contaminated. Radiation dose rates at waist level were 10 to $25 \mathrm{mrem} / \mathrm{h}$, with some small areas near the waste pits seeps containing ${ }^{106} \mathrm{Ru}$ as high as $100 \mathrm{mrem} / \mathrm{h}$. As the ${ }^{106} \mathrm{Ru}$ decayed, the dose rates dropped to 10 to $15 \mathrm{mrem} / \mathrm{h}$. These dose rates resulted largely from the ${ }^{60} \mathrm{Co}$ and ${ }^{137} \mathrm{Cs}$ concentrations in the soil. At that time this small piece of landscape was considered to be one of the most radioactive sites on Earth. We did not know then of the extensively contaminated sites in parts of the Soviet Union (e.g., Chyliabinsk, Kyshtym). The shift of the ecological research to the lake bed area and the waste pit area in 1956 marked a major change in the ORNL ecological research effort: the combining of ecology with radioactive waste disposal. The White Oak lake bed provided a totally new opportunity to approach this problem in an ecosystem context, namely, the opportunity to study the behavior and transport of radionuclides within the various producer and consumer components of a terrestrial ecosystem (see Auerbach et al. 1958, 1959, 1961). 


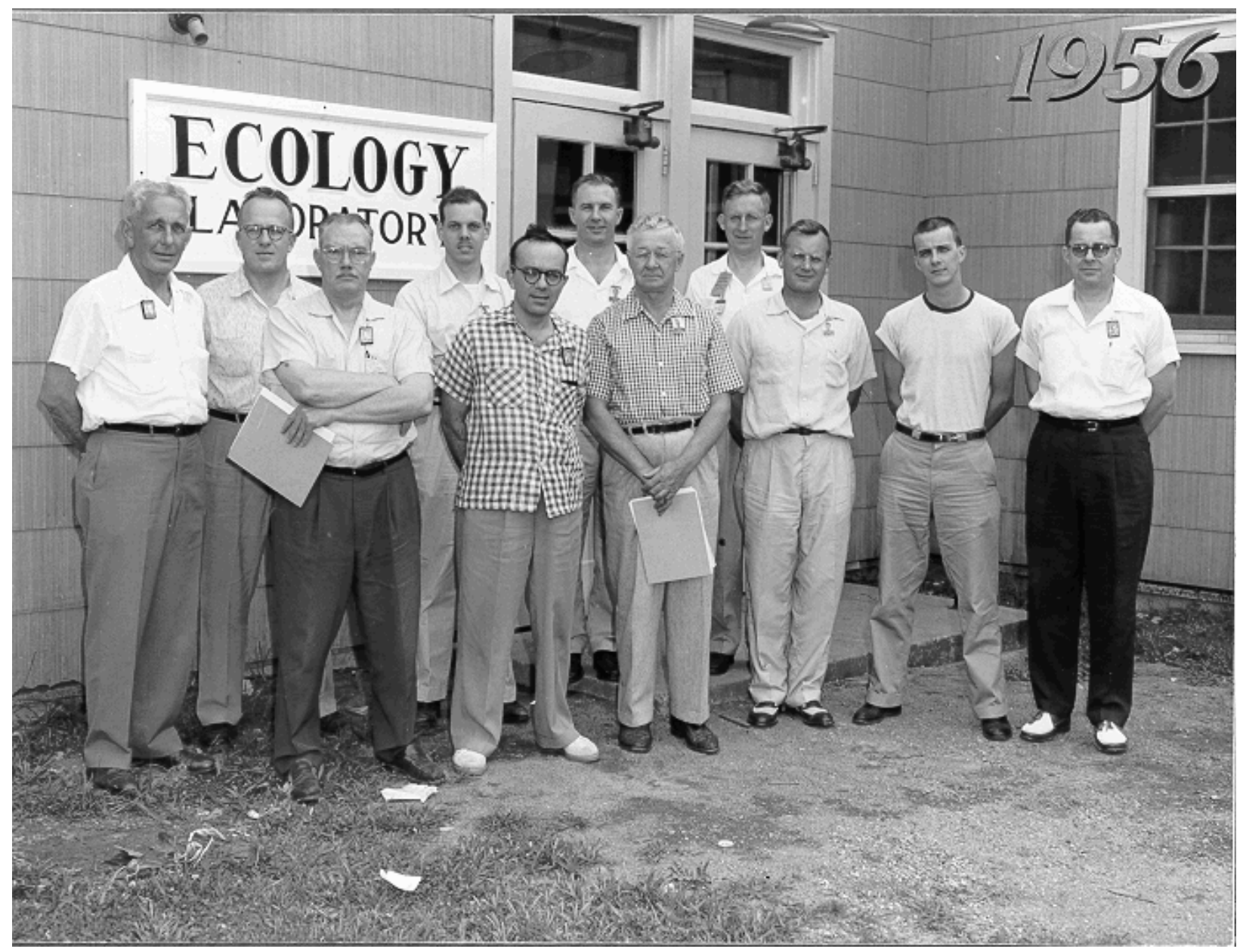

Fig. 1.3. Staff of the Ecology Laboratory at Oak Ridge National Laboratory in 1956 (the laboratory was housed at the Y-12 Plant from 1955 to 1961). From left to right are Roy Morton, Charles Rhode, Jr., Orlando Park, Manfred Engelmann, Stanley Auerbach, Kurt Bohnsack, James Lackey, Eugene Odum, Ellis Graham, Al Broseghini, and Ed Struxness. 
ORNL Photo 15903

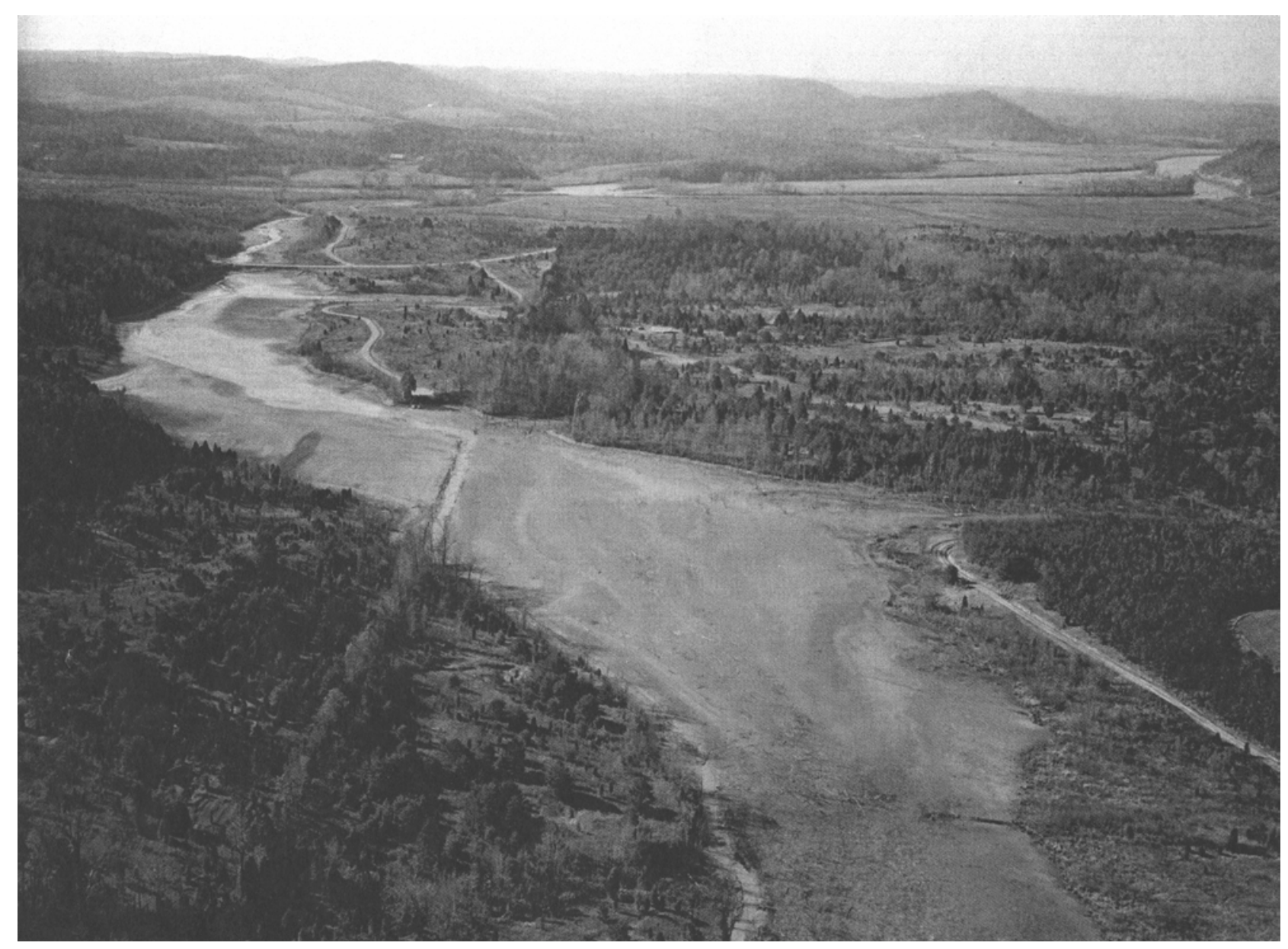

Fig. 1.4. Aerial photograph of drained White Oak Lake bed in 1955. 


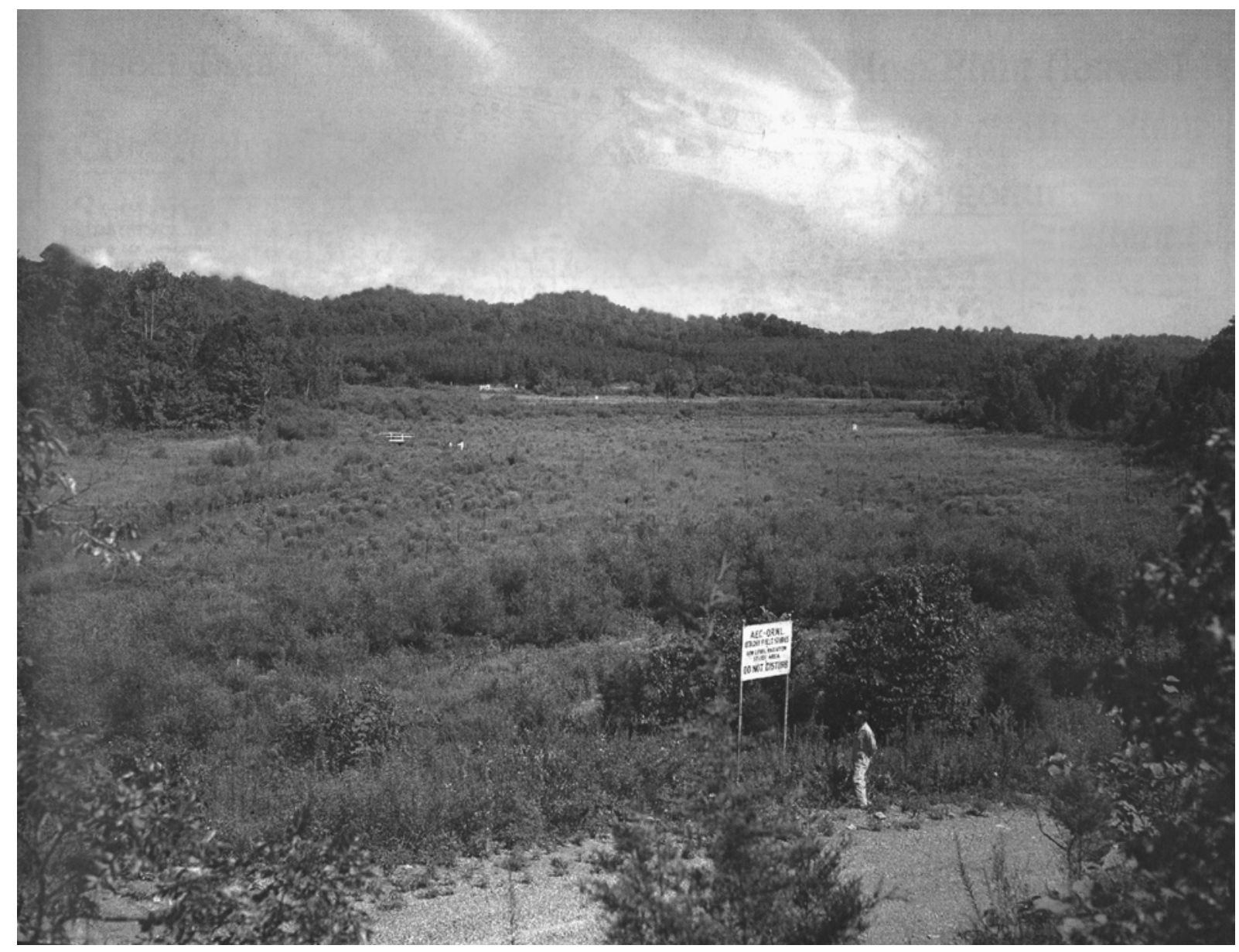

Fig. 1.5. Naturally revegetated White Oak Lake bed in 1958 where early radioecological studies were conducted. 


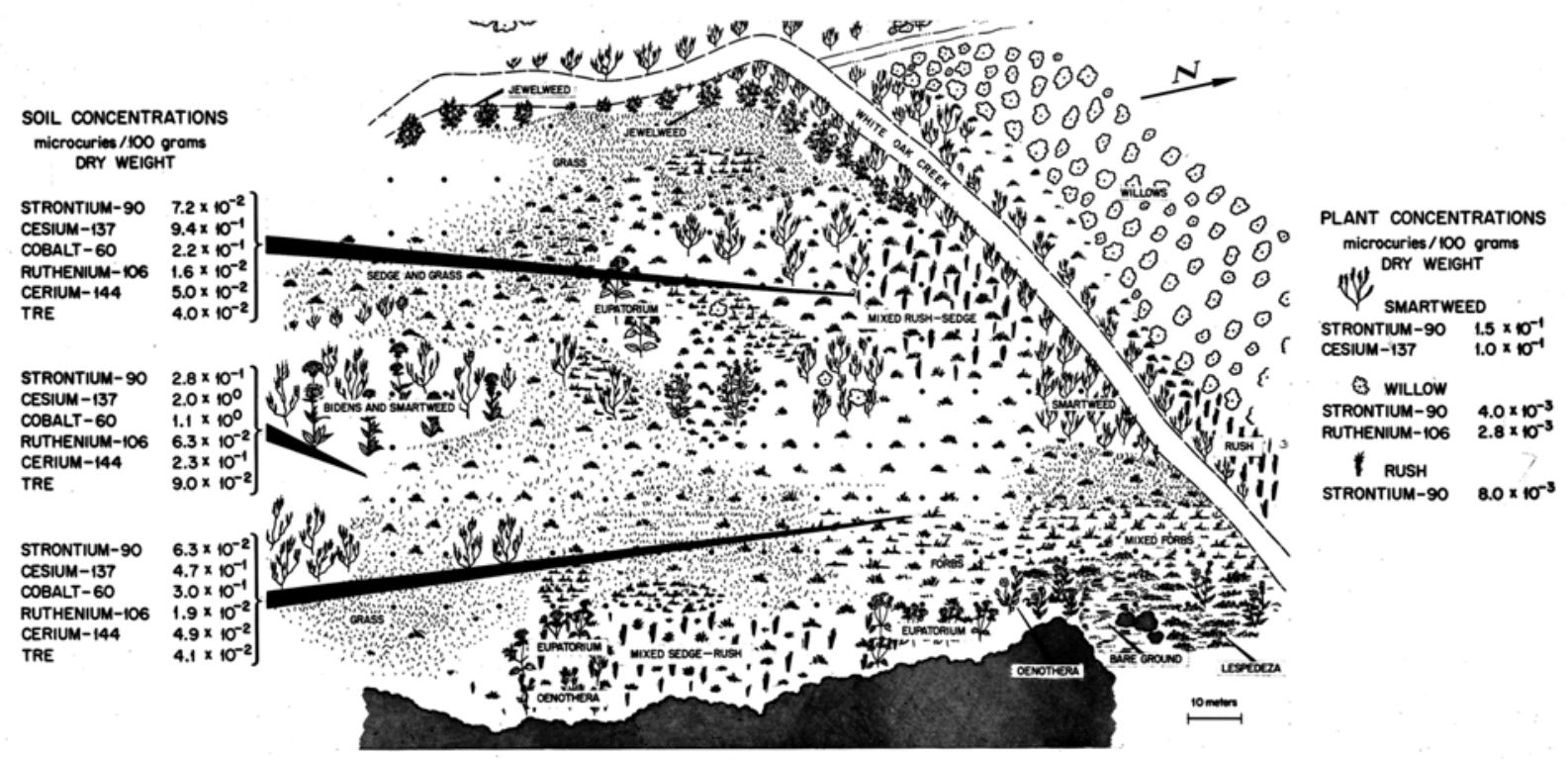

WHITE OAK LAKE BED, ECOLOGY STUDY AREA, DISTRIBUTION OF VEGETATION, JULY 1957.

Fig. 1.6. Radionuclide concentrations in soils and plants on White Oak Lake bed in 1957. 
This ecosystem-level approach to understanding and quantifying the accumulations and transfers from one component of an ecosystem (producers) to components that represented primary consumers and predators was a totally new approach, and, because it combined radioactivity and ecology, the term "radioecology" came into use. Coincidentally, about the same time in the former Soviet Union, an ecological research group led by A. A. Peredel'ski also was studying radioactivity problems from an ecological viewpoint. We did not and still do not know which of the then heavily contaminated Soviet sites his group worked on in 1956-1957, but he published a paper in 1958 in which used the term "radioecology" (Peredel'ski 1958).

Prior to establishing research sites, a radiation survey was carried out over the entire lake bed surface (Lee and Auerbach 1959); based on this information a 2.5-acre (1-hectare) study site was demarcated into a $10-$ by $10-\mathrm{m}$ grid interval system. The research groups then began an intensive mapping and sampling program of the vegetation and insect populations that developed rapidly there as a result of the high nutrient status of the soil, particularly from the nitrates, phosphates, and other chemicals that composed a major portion of the waste streams released from the laboratory. Soil sampling and analyses determined the structure, chemistry, and radionuclide content of the study area. The radionuclides of primary concern were ${ }^{90} \mathrm{Sr}$ and ${ }^{137} \mathrm{Cs}$ because of their abundance both in the radioactive wastes and in fallout from weapons testing. This factor, plus their long halflives, made them a primary concern for radiological protection. Figure 1.7 illustrates the concentrations of these isotopes in the soil and the organisms of the lake bed (Crossley 1963). In the study area, ${ }^{90} \mathrm{Sr}$ concentrations in soil averaged 360 picocuries per gram dry weight. Cesium-137 concentrations were 7300 picocuries per gram dry weight. Although ${ }^{137} \mathrm{Cs}$ was more abundant in soil than ${ }^{90} \mathrm{Sr}$ was, it was less available to vegetation, so the ${ }^{90} \mathrm{Sr}$ concentrations in plants were higher than the ${ }^{137} \mathrm{Cs}$ concentrations. Strontium-90 concentrations in plant leaves were above soil levels. Herbivorous insects contained about equal concentrations of the two radionuclides, because strontium is eliminated more rapidly than cesium; furthermore, their whole-body equilibrium values thus were much lower than concentrations in the host plants. Predaceous insects had approximately the same concentrations as did herbivorous insects.

From an ecosystem point of view, ecologists were interested in the quantities of radionuclides that were available and in their transfer through the food chains on a unit area basis, namely units of radioactivity per square meter of soils, vegetation, herbivorous insects, and predaceous insects. Such data provided the ecologists with the capability of calculating not only the uptake of radionuclides but also (using biological half-lives and turnover of vegetation biomass) the flow of radionuclides through the ecosystem on an annual basis. With these kinds of data, ecologists were able to project the long-term turnover and cycling of a particular radionuclide through an ecosystem.

This new approach provided a strikingly different perspective of the behavior of radionuclides in the environment (Crossley 1963). When the actual biomasses of the trophic levels are included, reduction in the transfer of radionuclides from one trophic level to another is the result (Fig. 1.8). This figure shows the distribution of radionuclides in the soil and biota on a square meter basis. The mass of soil overwhelms the masses of the organisms, so that the soil contained more than 99 percent of the radionuclides in the system. It should be noted that these data do not illustrate the quantities of radionuclides that pass through the insects feeding on plants. The concentrations in these organisms rapidly reach steady state equilibrium, so that the quantities of radionuclides ingested are 
ORNL 99-05753A/trh

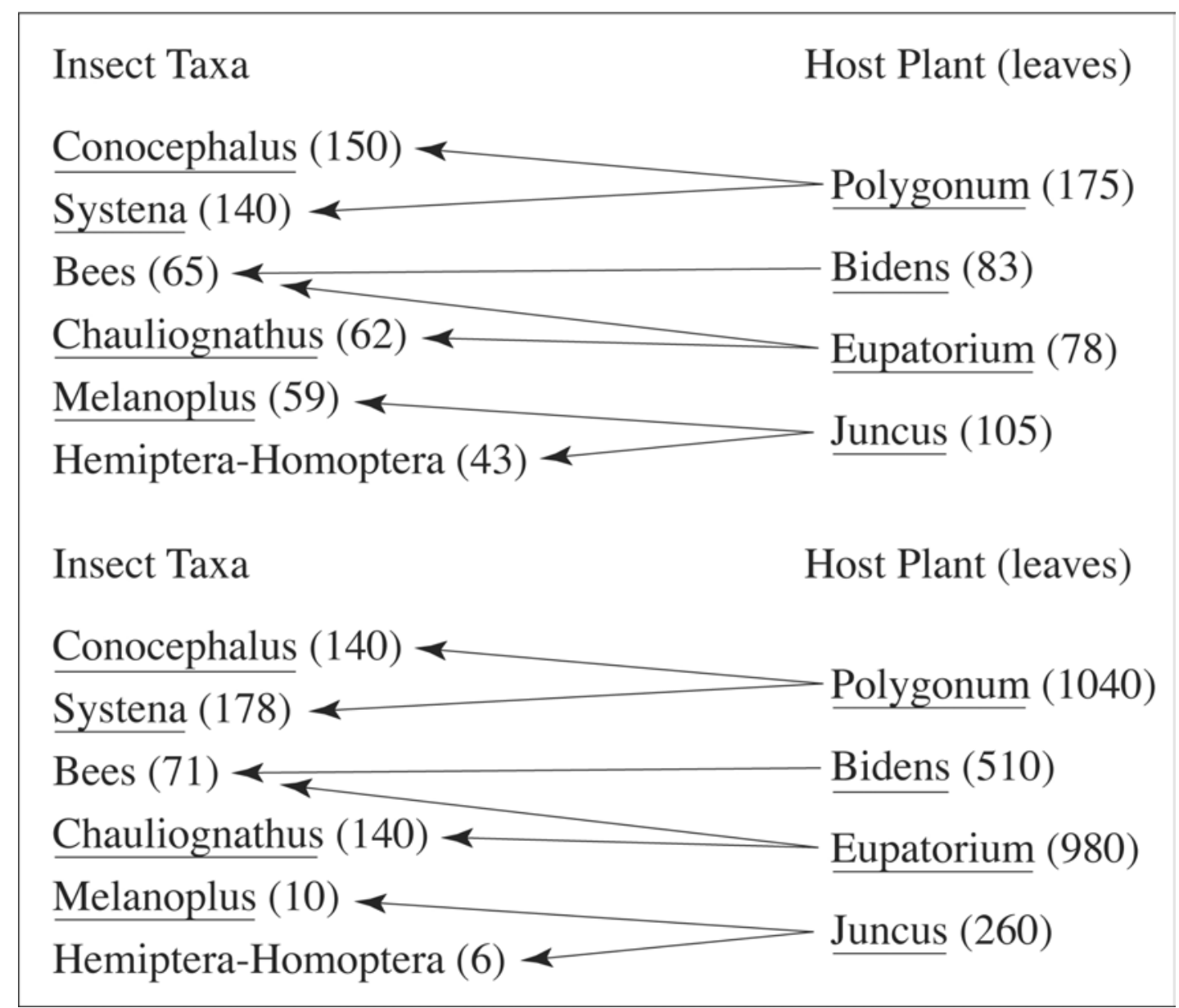

Fig. 1.7. Transfer of radionuclides from plants to insects on White Oak Lake bed: (top half) cesium-137 and (bottom half) strontium-90. Values in parentheses represent micromicrocuries per gram of dry weight of composite camples (from Crossley and Howden 1961). 


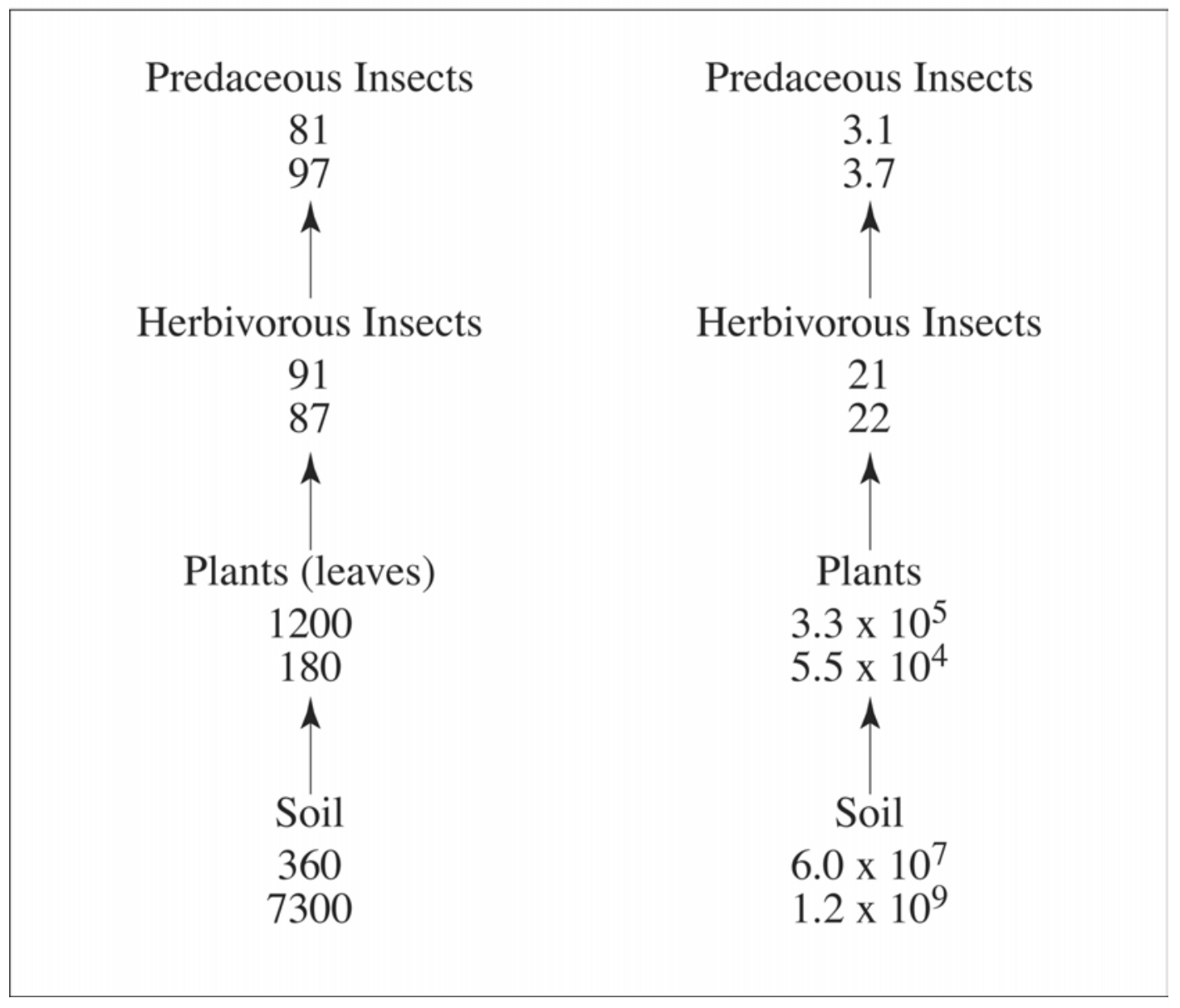

Fig. 1.8. Distribution of strontium-90 (upper value) and cesium-137 (lower value) in soil and biota at White Oak Lake bed: (left) in 1985, in micromicrocuries per gram of dry weight of a composite sample (from Crossley 1963). 
equal to the quantities being eliminated. These data and their implications would not necessarily apply to other food chains, especially those in which organisms whose organ systems and skeleton would accumulate particular radionuclides (e.g., bone structures in bird and mammals). Nevertheless, what was determined then is that the concentration of radionuclides in food chains will depend upon the elimination coefficients and resulting concentration factors in each step or linkage of a food chain.

When the quantities of radionuclides in the ecological trophic levels (e.g. picocuries per square meter) are considered, great reductions of radionuclides occurred during the transfer of radioactive materials from one trophic level to the next higher trophic level. The magnitude of the values at each trophic level was found to be more dependent upon the mass of organisms than upon the concentrations of radionuclides in the organisms. Calculations using the radioisotopes in this lake bed system as tracers also provided the means for calculating the amount of food consumed by the organisms. The insects consumed approximately $6 \%$ of the plant biomass during a growing season. A new radiological technique was now available to measure herbivory and predation in natural ecosystems (Reichle 1967; Reichle and Crossley 1967).

Waste Pit Studies. As noted earlier, in the mid-1950s, ORNL experimented with the concept of disposing of large volumes of what was then called intermediate-level wastes. The pits were both operational and experimental at the same time. They were experimental in that they were located in a shale formation, which had been found to have high sorptive properties for a number of fission products and therefore was being considered for a possible approach to dealing with large volumes of liquid wastes. The pits were also operational in that they were used as receiving basins for the large quantities of intermediate-level radioactive wastes that were generated by the fuel element re-processing carried out at ORNL. Thousands of curies of ${ }^{90} \mathrm{Sr},{ }^{137} \mathrm{Cs},{ }^{60} \mathrm{Co}$, and ${ }^{106} \mathrm{Ru}$ were sent to these pits. With the exception of ${ }^{106} \mathrm{Ru}$, the radionuclides were retained to a considerable extent by the soil immediately surrounding the pits.

In 1957 the ecology program was directed by the AEC to carry out an extensive sampling program for radionuclides, particularly ${ }^{106} \mathrm{Ru}$ in the tree stands that grew around the pits. The purpose was to ascertain whether the root systems were absorbing radionuclides that might be leaking from the pits and that could not be detected by other sampling methods. An extensive tree sampling program was carried out in 1957 and 1958 with particular emphasis on the presence and distribution of ${ }^{106} \mathrm{Ru}$ in the forest stands that dominated the waste pit site. Although ${ }^{106} \mathrm{Ru}$ was detected in many of the individual trees, the distribution was highly variable, both within single trees as well as between trees. Analyses of the available data did not yield any correlation between distances from the pits, between individual trees as a function of location, or even within individual trees. These results were largely due to the limited biological affinity for ruthenium as well as to uncertain knowledge of the subsoil seepage patterns (Auerbach and Olson 1963). The positive result of this investigation is that it identified and supported the need for researchers to carry out forest experiments on the behavior and cycling of fission products, using single species of radioisotopes in individual tree species (Witherspoon 1963). The individual tree experiments ultimately led to the $1962{ }^{137}$ Cs forest ecosystem experiment, in which an entire forest ecosystem was experimentally labeled with a radioisotope (Auerbach, Olson, and Waller 1964). 


\subsubsection{Savannah River}

At the beginning of the $1950 \mathrm{~s}$, the AEC decided that a second major plutonium production site was needed. Two hundred thousand acres in the Piedmont region along the Savannah River in South Carolina was selected. The site was mixed forest, abandoned agricultural land, and replanted pine plantations. Without the urgent schedules of the Manhattan Engineer District, there was time to do preliminary ecological work before plant construction, and in 1951 the AEC made arrangements with Eugene Odum at the University of Georgia for an ecological inventory and a plan for ecosystem research. Research was begun "out of suitcases and an abandoned barn," and soon a vacated home was obtained for a field station (Stannard 1988). This operation ultimately became the Savannah River Ecology Laboratory.

Later, in the 1960s, after the Savannah River Plant was constructed and began operating, a diverse radioecology program evolved. Large quantities of tritium were emitted from the stacks. The usual radionuclides were in wastewater streams, and the usual problems of waste disposal existed. In addition, large quantities of warm water were discharged from reactor cooling, introducing the ecological problem of thermal stress. Most of the work on radionuclides focused on assessment of releases (Bebbington 1973), but the classic ecological research basis had been summarized by Odum (1956) at the First Atoms for Peace Conference in Geneva in 1955. He stressed the importance of understanding the effects of radiation on higher levels of biological organisms - the population, community, and ecosystem levels. He also hinted at the importance of biogeochemical cycles in the context of the safe disposal of radioactive waste products. He laid out the scientific basis for the developing ecology program at the Savannah River site by calling for studies on the effects of radiation on trophic structure, productivity, and metabolic properties of ecosystems, emphasizing the comparison of contaminated and noncontaminated areas. This was state-of-the-art functional ecology with one new variable - radioactivity. The results of Odum's radioecological research during the late 1950s were reported at the First International Symposium on Radioecology in Fort Collins, Colorado (Odum 1963).

Odum and his colleagues began their trophic studies in the spring of 1957 , using ${ }^{32} \mathrm{P}$ to isolate individual food chains of intact, natural communities in an old field ecosystem that had been established five years after corn and cotton agriculture had been abandoned. Their premise was simply that if they labeled foliage of related plants, any radioactive herbivorous insects they subsequently found could be determined to be grazers upon those plants, and any radioactive predators they found could, in turn, be connected to the prey herbivores. Ingenious in concept and simple in experimental design, the studies yielded some exciting findings.

The clearest and most profound result of these experiments was the graphic separation of certain trophic and habitat groups when the concentration of ${ }^{32} \mathrm{P}$ per unit of biomass was plotted against time. Figure 1.9 illustrates these results for a simple community Rumex acetocella, an annual forb; Oecanthus nigricornus, an orthopteran grazing herbivore; Dorymyrmex pyramicus, an ant; Succinea campestris, a snail occurring on vegetation and on the ground; spiders (primarily Lycosa timuqua and L. carolinesis); and ground-dwelling cryptozoa (Blattids [roaches], Gryllids [crickets], Carabids [ground beetles], Tenebrionids [darkling beetles], and Isopterans [termites]) of mixed trophic structure and probably predominantly saprophagous. The key in these data was the time intervals 
required for peak concentrations of ${ }^{32} \mathrm{P}$ to appear, with herbivores first, predators second, and finally crypotozoa (saprophages). The data also suggested that some species might be omnivorous feeders. A result from other data not illustrated in Figure 1.9 was that the more common groups of herbivores were not plant-specific feeders, and ground-dwelling crypotozoans were feeding above ground at night. Complexity in the trophic structure (herbivore, omnivore, carnivore, saprophage) and diversity in plant host and prey food bases all served to hint at the complexity of natural ecosystems, a complexity that radioecologists in the following decades would be challenged to unravel and understand.

\subsection{SCIENTIFIC LEGACIES FROM THE 1950s}

Many of the concepts and analytical tools developed very early by the field of radioecology are still pertinent today and have had a marked influence on the development of regulatory standards, as well as on scientific progress in the field of ecosystem ecology.

\subsubsection{Radiotracers in Ecology}

Following the applications of radiotracers in health physics, radiopharmacology, and agriculture, in which isotopic tracers were being used to study the dynamics of biological systems, ecologists also began radiotracer applications in ecosystems to study food chain behavior, bioaccumulation, and environmental fate. By the late 1940s, isotopic releases from nuclear operations had already demonstrated the utility of radiotracers for studying mineral nutrition and biogeochemical pathways, and by the early 1950s ecologists were using radioisotopes experimentally in aquatic and terrestrial ecosystems. These early ventures were to open the field of ecology to new areas of experimental study. The pioneering studies of the 1950s were reported in the 1960 proceedings from the symposium on radioisotopes in the biosphere, which was organized by R. S. Caldecott and L. A. Snyder and held at the University of Minnesota in 1959, and also in the 1963 proceedings of the First International Symposium on Radioecology, which was organized by Dr. Alfred Klement, Jr., and Dr. Vincent Schultz and held at Fort Collins, Colorado, in 1961.

\subsubsection{Food Chain Dynamics}

Radionuclide tracers enabled a whole new field of research on the critical pathways of the movement of pollutants in the environment and their potential for food chain discrimination or bioaccumulation in successively higher trophic levels. Sophisticated mathematical equations were developed, permitting calculation of the time dynamic (transient behavior) of whole-body concentrations and equilibrium whole-body burdens from both acute and chronic ingestion. Some isotopes, such as the bone-seeking strontium isotope, were found to have concentration factors much greater than 1.0 (similar to fat-soluble and accumulating pesticides such as DDT), whereas the concentration of others equilibrated after the first trophic level exchange, or even decreased (e.g., Reichle, Dunaway, and Nelson 1970). Significant variability also existed in soil-plant uptake which was dependent upon soil chemistry and plant nutrition. Nutritional requirements and organisms' metabolism of elements, reflected in isotopic turnover (elimination rates and biological half-lives), determines the food chain transient and the whole-body concentrations. Food chains inherently neither concentrate nor dilute pollutants, but this, 
ORNL 99-05755A/trh

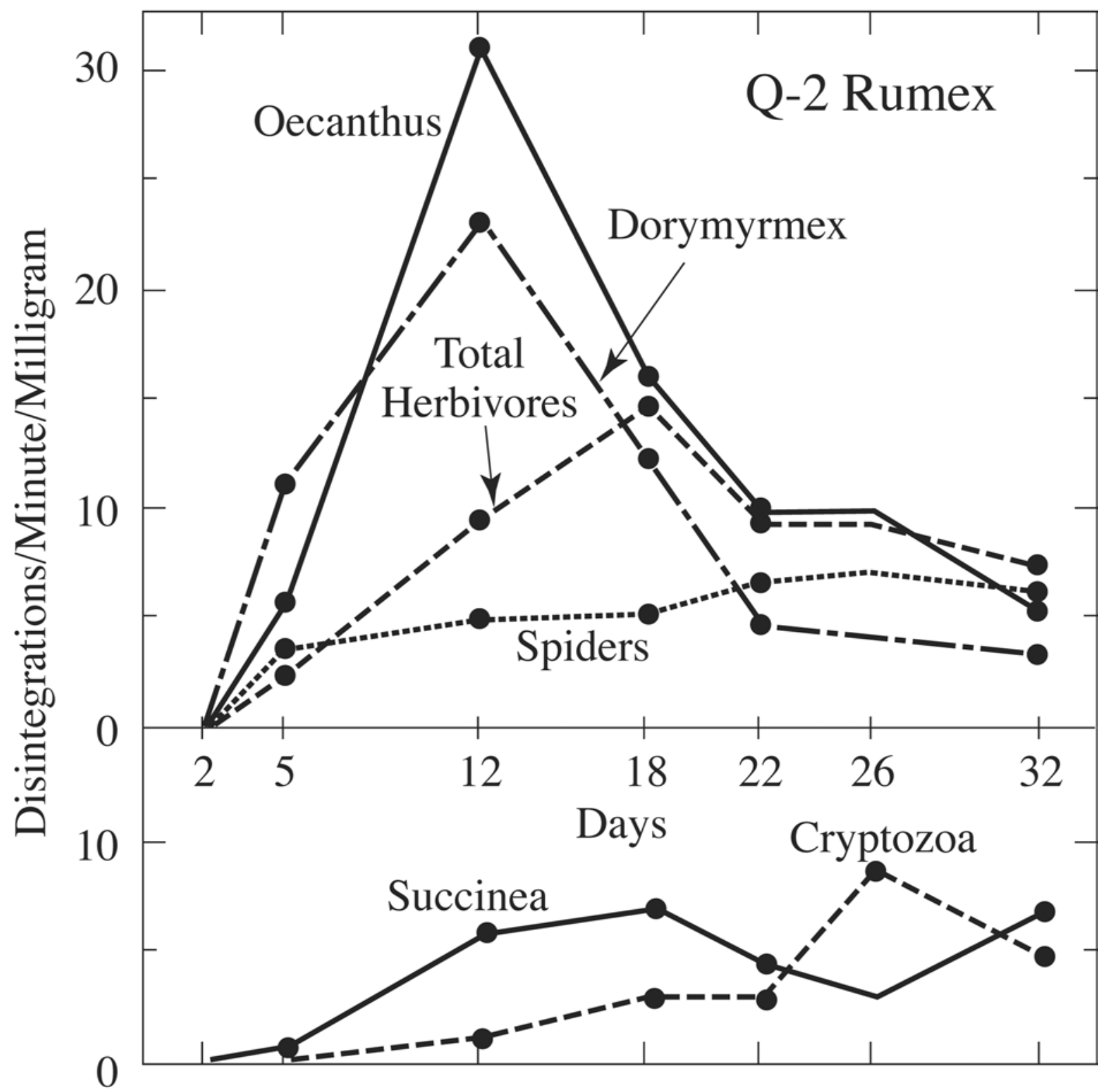

Fig. 1.9. Radiotracer studies of food chains at the Savannah River Site. The concentration of phosphorus-3 was measured in six animal populations in Quadrant 2, where Rumex was the main vegetation. 
fact continues to be misunderstood in the public's perception of the behavior of hazardous materials in the environment. Food chain models have had important application in developing regulatory standards for environmental exposures (ingestion) and in developing risk analysis for chemical releases.

\subsubsection{Environmental Protection}

Early research on the health effects of nuclear energy occurred during the Manhattan Project, and soon thereafter the AEC developed an extensive biology program, which was in place by the early 1950s (including the "megamouse" genetics program at Oak Ridge).

Nevertheless, the utility of a broad-based ecology enterprise was not appreciated by many at the AEC. The idea was still widely held that, if a man was acceptably protected, then his environment would automatically be protected. The fact that man is an "integral part of his environment" had not yet become generally appreciated. Much of the development of radioecology within the AEC was due to the farsighted vision and encouragement of Charles Dunham, M.D., who became chief of the AEC's Division of Biology and Medicine (DBM) in 1955 . Some programs were already under way in the early 1950 s by Dr. Richard Foster at Hanford and by the mid-1950s by Dr. Stanley Auerbach at ORNL and Dr. Eugene Odum (University of Georgia) at Savannah River. By 1958 an Environmental Branch was developed within DBM, and Dr. John Wolfe, an ecologist, became its director. Support for the large-scale, field-based experimental ecology in both the national laboratories and universities in the United States began with the AEC because of concerns about nuclear energy and the environment. Only later in the 1970s did the National Science Foundation became a principal research sponsor for ecosystem research.

\subsubsection{Regulations and Science}

The rapidly expanding base of knowledge about the biological and ecological effects of radiation led to ever more restrictive environmental radiation protection standards, particularly during in the late 1950s. This trend has continued until the present, driven by continued improvement in our scientific understanding of ecological systems, advances in analytic technologies and measurement standards, accelerated federal standards in the 1970s, and expectations for the nuclear industry and R\&D laboratories to adhere to ALARA (as low as reasonably achievable) for radiation exposures. Ever increasing restrictions on (a lowering of) permissible radioactive emissions have made understanding the dynamics of ecological systems even more important (Reichle and Auerbach 1972). Much more precise information, with less uncertainty, is needed about the fate and behavior of radioactive contaminants in the environment.

\subsubsection{The Dynamic Nature of Ecosystems Revealed}

It became very clear, very early, that the behavior of radionuclides in the environment was a dynamic phenomenon. Many biological and environmental parameters contributed to the inherent variability of ecological systems. To have a mechanistic, predictive capability for complex behavior in non-linear systems with internal feedback, simulation modeling of ecological systems ultimately became necessary. The foundations for ecological modeling were laid in the late 1950s and began in earnest in the 1960s (Olson 1963), contributing to the development of the new field of systems ecology. 


\subsubsection{The Unfulfilled Promise}

The behavior of radionuclides in the environment is governed by a complex and variable set of natural processes and by the diversity of ecosystems in which they occur. Almost every component of an ecosystem will have some influence upon the pathways, dynamics, and ultimate distribution of radioactive materials introduced into the system. While applications of radiotracer technology to biogeochemical cycling in ecosystems opened new opportunities to explore elemental dynamics in the environment, there was a pitfall. The ease with which radionuclide tracers could be measured created a wealth of information for different elements in different ecosystems. But, the underlying physical, chemical, and biological variables that control elemental dynamics were not adequately quantified. Thus, much knowledge accumulated about the specific behavior of specific radionuclides in specific ecosystems under specific conditions, but the ability to predict the system dynamics under different conditions for other isotopes or different ecosystems was limited. The most progress was made in soil chemistry, but just as the scientific community began to recognize the importance of obtaining mechanistic, process-level data in the mid to late 1960s, the shift and interests in large-scale field radioecological research in the AEC began to wane. Thereafter, these important advances were never realized in the American research program, but they were continued later in the 1970s in Europe, with the establishment and support of the European Commission and the establishment of the International Union of Radioecology. The Chernobyl accident on April 26, 1986, provided an additional stimulus for European radioecology research in recent years. 


\section{U.S. ATOMIC ENERGY COMMISSION'S ENVIRONMENTAL RESEARCH PROGRAMS ESTABLISHED IN THE 1950s}

In 1946 the United States Congress passed the Atomic Energy Act and with it created the Atomic Energy Commission (AEC). For the ensuing half-century, the AEC and its successors pursued biological and environmental research with an unwavering mandate to exploit the use of fissionable and radioactive material for medical purposes and, at the same time, to ensure the health of its workers, the public, and the environment during energy technology development and use (AEC 1961; DOE 1983; DOE 1997). The following pages are testimony to the success of this undeviating vision (see milestones, Table 2.1). From the early days of the AEC, cooperation has also linked researchers from the national laboratories, the academic community, and the private sector. The AEC sponsored research at national laboratories and universities and also supported graduate students to develop a cadre of health physicists, radiation biologists, and nuclear engineers. Coordinating these diverse performers has been crucial to the unique teaming that has made many of the successes possible. The success of the biological and environmental research program has often been shared with other federal agencies. The future will demand even stronger and more substantive intra-agency, interagency, and international collaborations.

The earliest glimmering of radioactivity's promise long predated any sense that ours would be the Atomic Age. By the time of the Manhattan Project, physicists had almost a halfcentury of experience with X-rays and radioactive elements and their radiation, and several such elements, most notably radium, had been used since the turn of the century in efforts to treat human disease. By the 1930s, radioactive isotopes were being produced artificially in Berkeley's cyclotrons, and the pace of medical use and biological experimentation increased dramatically. At the same time, even the earliest pioneers saw that radioactivity was not a benign blessing; protection standards, albeit far from adequate, were published as early as 1915. Nonetheless, it was World War II that firmly thrust the nuclear genie onto the public stage. At first the spotlight was on the awesome power of the atom and then on the emerging promise of nuclear energy, but splitting the atom would also herald a vital new era for biology, medicine, and environmental research (Stannard 1988).

Even during the war years, biological research was a priority. A Medical Advisory Committee chaired by Stafford Warren developed health and safety policy for the Manhattan Project and inaugurated research programs to ensure adequate protection for project workers. Teams of physicians, biologists, chemists, and physicists worked to learn how isotopes and their radiation affected the body, what protective measures were most effective, and, in the event of mishap, what methods of diagnosis and treatment were best. At the war's conclusion, recognizing the opportunities of atomic energy - and acknowledging, too, an obligation for public safety- the Congress passed the Atomic Energy Act of 1946, which would transfer responsibility for atomic energy research and development from the War Department to an independent civilian agency, the Atomic Energy Commission. On

January 1, 1947, the AEC thus took charge of research programs in health measures and radiation biology conducted in government facilities at the Clinton Laboratories (now Oak Ridge National Laboratory), Hanford, and Los Alamos; at the Metallurgical Laboratory at the University of Chicago (now Argonne National Laboratory); and at many university laboratories, large and small. Among the ongoing efforts were health physics research for "improving our knowledge of the potential dangers presented by fissionable materials, 
reactors, and fission products and for proposing methods of elucidating or circumscribing 
Table 2.1. Milestones in the U.S. Atomic Energy Commission's (now U.S. Department of Energy's) environmental research program during the decade of the 1950s

1946 The Atomic Energy Act of 1946 establishes the Atomic Energy Commission (AEC). Radioecological studies of the Hanford environs and the Columbia River lab by Richard Foster and Jerry Davis are already under way.

1947 The AEC establishes the Division of Biology and Medicine (later known as Division of Biomedical and Environmental Research [1974], Office of Health and Environmental Research [1977], Office of Biological and Environmental Research [1997]).

1949 Brookhaven scientists begin a thirtyyear program aimed at assessing the effect of radiation on living plants. Much of the work will take place at the cultivated Gamma Field established in 1951. Results here and at Oak Ridge will confirm Brookhaven predictions that relative radiosensitivity among plant species varies with nuclear volume and chromosome size.

1950 Using phosphorus-32 in a Connecticut lake, Evelyn Hutchinson at Yale documents the quantitative cycling of the element-an essential and often limiting nutrient-within a lake ecosystem. The initial radioecological survey at Oak Ridge is conducted by Louie Krumholz of the Tennessee Valley Authority.

1951 The AEC supports the establishment of the Laboratory of Radiation Ecology at Savannah River, directed by Eugene Odum of the University of Georgia.

1955 At the First International Conference of the Peaceful Uses of Atomic Energy, held in Geneva, Switzerland, Richard Foster and Jerry Davis summarize nearly a decade of measurements in the behavior of radionuclides in Columbia River waters and aquatic biota at the Hanford Site.

1955 The radioecology program in Oak Ridge is formally established by Stanley Auerbach, who initiates over the next two years the first experimental radioecological studies in terrestrial ecosystems on White
Oak lake bed. Ed Struxness and Frank Parker initiate the Clinch River health physics studies of the off-site movement of radionuclides.

1955 Early efforts to understand atmospheric transport and dispersion lead to the publication of Meteorology and Atomic Energy, which quickly becomes a basic meteorological reference. A second edition, published in 1968, would for years remain the definitive reference for small-scale meteorology. By 1984 it would evolve into the thousand-page volume, Atmospheric Science and Power Production.

1956 The Environmental Research Branch is created within the AEC's Division of Biology and Medicine for "research pertaining to man and his environment, including disciplines such as ecology, oceanography, marine biology, geophysics, and meteorology."

1959 Symposium on Radioisotopes in the Bisophere at the University of Minnesota overviews the environmental concerns and knowledge at the end of the decade.

1959 Wallace Broecker at Columbia University uses natural radiocarbon in the ocean to quantify ocean circulation processes.

1960 In advance of the proposed use of nuclear explosions to excavate a harbor near Cape Thompson, Alaska, AEC-sponsored scientists begin an exhaustive ecological survey of the area. This "environmental assessment" predated by almost a decade the requirements of the National Environmental Policy Act of 1969.

1960 University of Wisconsin scientists use radiosodium and radioiodine to document the physical and biological mechanisms of material mixing and transport in a chemically stratified lake.

1961 The research of the 1950s is summarized at the First International Symposium on Radioecology (organized by Vince Schultz and Art Klement, Jr.), in Fort Collins, Colorado. 
such dangers"; research aimed at extending our "fundamental knowledge of the interaction of nuclear radiation and living matter"; and radioisotope distribution programs to "provide indirect aid to research in many fields of biological and medical research."

The entire AEC budget for fiscal 1947 was $\$ 342$ million, only a fraction of which was for biological, medical, and environmental research.

Early in its first year, the AEC moved to provide a solid foundation for its biomedical research and education efforts by asking the President of the National Academy of Sciences to nominate a panel of experts as a Medical Board of Review to advise the Commission. The Board was promptly established, and by June it had issued its initial recommendations, broadly supporting biomedical research and training efforts and proposing a permanent Advisory Committee for Biology and Medicine (ACBM). In September 1947, the chairman of the AEC appointed seven distinguished physicians and biologists to the ACBM.

Immediately upon its creation, the ACBM recommended that a Division of Biology and Medicine be established to "coordinate medical, biological, and biophysical (health physics) research programs related to atomic energy" and to "direct for the Commission its health physics works and industrial hygiene activities." The recommendation was quickly adopted. Thus was forged a commitment that has endured for a half-century-a commitment to vigorous research aimed both at nurturing the fruitful use of a new technology in the life sciences and at ensuring public health and safety in the face of that technology's perils. In 1955 Dr. Charles Dunham became director of the AEC Division of Biology and Medicine and in 1956 created the Environmental Research Branch (with John Wolfe as director) for "research pertaining to man and his environment, including disciplines such as ecology, oceanography, marine biology, geophysics, and meteorology." The historical timeline for these organizations in the AEC, and its successors, is shown in Table 2.2.

In matters of the environment, public awareness lagged far behind the activities of the energy agencies. As early as the 1940s and 1950s, in an era when most people had never even heard the word "ecology," the AEC was forging an enviable record of environmental and ecological research. The initial catalyst was again the development of nuclear weapons and the two decades of atmospheric testing that followed. Estimating the health effects of released radioactivity depended not only on epidemiology, genetics, and radiation biology, but also on knowing the fates of the airborne radioisotopes in the first place. Meteorology and oceanography were as important as biology — as was research into the ecological processes that cycled materials through plants and animals to human beings. Atmospheric and environmental studies thus fell naturally within the purview of biomedical research. The impact of atomic energy on the environment and on the environmental sciences was profound (Wolfe 1963).

\subsection{THE ATMOSPHERE}

In the postwar years, responsibility for radioactive fallout monitoring was spread among several laboratories. Chief among them was the Health and Safety Laboratory (now the Environmental Measurements Laboratory) in New York City, which established the earliest and most authoritative monitoring network in the world and ultimately produced an integrated history of the distribution of nuclear weapons debris in the air, on land, and 


\section{Table 2.2. Timeline of Organizational Nomenclature}

1946 Atomic Energy Commission (AEC) is established

1947 AEC Division of Biology and Medicine (DBM) is established

1956 AEC Environmental Research Branch is created in DBM

1974 AEC is renamed Energy Research and Development Administration (ERDA)

1974 ERDA Division of Biology and Medicine is renamed ERDA Division of Biomedical and Environmental Research

1977 ERDA is renamed U.S. Department of Energy (DOE)

1977 DOE Division of Biomedical and Environmental Research is renamed DOE Office of Health and Environmental Research (OHER)

1997 DOE Office of Health and Environmental Research is renamed DOE Office of Biological and Environmental Research (OBER)

in water, as well as in plants and animals, especially the human food chain. As part of the High-Altitude Sampling Program, for example, instrumented balloons and aircraft were sent aloft to sample the stratosphere and to assess the exchanges of material between the stratosphere and the lower atmosphere. The resulting data contributed in a concrete way to the international moratorium on above-ground testing later in 1963.

Beyond measurement, however, lay the more daunting challenge of prediction-a challenge that would naturally breed three distinct research thrusts: inquiries into the transport of radioactive materials released near the ground (a situation that might arise following, say, an accident at a weapons production facility), research into how clouds scavenge radionuclides and then deposit them in rain, and efforts to understand the global transport of materials released during atmospheric weapons tests.

In pursuit of answers to the near-surface question, several of the national laboratories installed meteorological facilities, including several Air Resources Laboratory (ARL) facilities operated by the U.S. Weather Bureau for the AEC. Their investigators sought scientific methods to predict how airborne materials are transported in the lower atmosphere and how their eventual deposition depends on the nature of the material and on atmospheric and topographic variables, including the presence of complex mountainous terrain. Using the collective results of these efforts, Frank Gifford and his colleagues at the ARL Atmospheric Turbulence and Diffusion Laboratory in Oak Ridge then developed a set of curves for calculating the spread of pollution from a "point source." In a time when the slide rule was the dominant computational tool, these 
dispersion models won international acceptance as tools for predicting the fate of nuclear reactor emissions and industrial pollutants.

A natural part of the effort to understand atmospheric dynamics was the use of tracers to track the movement of materials, both locally and around the globe - not unlike the use of radionuclides to follow dynamic processes in the human body. Early "tracers of opportunity" included such natural constituents of the atmosphere as spores and ozone, as well as power plant emissions and debris from weapons tests. In at least one case, a nuclear weapon was even "salted" with tungsten, which could be conveniently traced around the world. In 1955, early efforts to understand atmospheric transport and dispersion led to the publication of Meteorology and Atomic Energy, which quickly became a basic meteorological reference. A second edition, published in 1968, would for years remain the definitive reference for small-scale meteorology. By 1984 it had evolved into the 850-page volume Atmospheric Science and Power Production (Randerson 1984).

\subsection{CLIMATE}

In the area of atmospheric studies, the legacy of the 1950s and 1960s has thus been especially fertile. But perhaps the richest payoff has been a heightened awareness of our atmosphere's complexity and, in turn, a keener appreciation of its sensitivity to human activity. The third of the AEC's major research thrusts - atmospheric dynamics on a global scale - contributed in an especially important way to this growing environmental awareness. In the early 1960s, the AEC's interest was the global transport of weapons test debris. Accordingly, at Livermore, mathematical physicist Cecil Leith was one of only a handful of researchers in the world using the emerging power of scientific computing to simulate global atmospheric dynamics. Later, he would move on to the new National Center for Atmospheric Research (NCAR) in Boulder, Colorado, where he established its reputation as one of the world's leaders in developing atmospheric general circulation models (GCMs) - advanced climate models that provide not short-term meteorological forecasts, but rather long-range prognoses of global climate.

Today, global climate change research continues as a vigorous multi-agency priority, propelled by the issue's overarching importance and challenged by the profound complexity of atmospheric and biological processes. DOE is now one of several federal agencies, notably NASA, the National Science Foundation, and the National Oceanic and Atmospheric Administration, which working as partners to predict future concentrations of greenhouse gases, to assess their likely effects on the climate, and to evaluate the resulting biological and economic impacts.

\subsection{THE DYNAMIC OCEAN}

Perhaps even more deeply mysterious than atmospheric dynamics are the workings of the oceans. From the earliest days of atmospheric testing, the AEC sought to understand the fate of radioactive fallout over Pacific waters and whether radioactive waste could be safely disposed of in the ocean depths. But the agency's interest was greatly heightened in 1954, when a Japanese fishing boat and its cargo of fish were contaminated following a Pacific Ocean nuclear test. Suddenly, the sea and its denizens were subjects of intense 
inquiry. Ensuing AEC support for oceanic research reaped unexpected rewards.

One of the pioneers was Wallace Broecker, of Columbia University's Lamont-Doherty Geological Observatory (now the Lamont-Doherty Earth Observatory). Soon after the 1954 incident, he began using natural and bomb-generated radionuclides as "clocks" to study ocean dynamics. By measuring the ratios of carbon isotopes, for example, he found that, whereas the average $\mathrm{CO}_{2}$ molecule remains in the atmosphere for seven years, bottom water in the Pacific Ocean turns over only once every thousand years. His analyses of $\mathrm{CO}_{2}$ absorption by the oceans also provided new data on the fate of atmospheric $\mathrm{CO}_{2}$ more than a decade before it would become an important climate change issue. Broecker's methods were seminal: distributions of stable and radioactive isotopes were subsequently used to measure the accumulation rates of deep-sea sediments and to develop the first records of climate change in the past. Broecker also turned to radionuclides as tracers. Using strontium-90 from fallout, for example, he was able to define the Atlantic Ocean "conveyor belt" that operates between Greenland and the equatorial tropics. In 1996, in part for work supported by the AEC, he was awarded the Presidential Medal of Science.

\subsection{THE BIOSPHERE}

Broeker's prescient work on ocean ecosystems points to yet another strand of environmental research, one intricately entwined with studies of atmospheric and oceanic dynamics and the dispersion of airborne and waterborne contaminants. Its early theme was the fate and effects of radioactivity released into terrestrial and fresh-water ecosystems. In concert with research on human health effects, these strands of environmental exploration thus sought a complete picture of the impacts of nuclear technology: What is the fate of the radioactive materials we release? What are their direct effects on humans? And what are their near- and long-term effects on the biosphere of which we are a part? The early efforts would broaden decades later in the 1970s to encompass all energy-related emissions, but the larger question would remain the same: what are the consequences of the energy choices we make?

In approaching such questions, the AEC's most pervasive contribution followed the theme of its efforts in nuclear medicine and atmospheric studies, namely, the use of radioactive tracers. Beginning with modest efforts at several universities and national laboratories (Caldecott and Snyder 1960), radioecology grew to encompass studies of material pathways and flow rates through terrestrial and aquatic ecosystems of every description (Schultz and Klement 1963). The research involved nearly all of the AEC national laboratories, in part because of their locations in different environments of the country (Figure 2.1).

At first, radiotracer studies led by Richard Foster dealt mainly with iodine-131, a shortlived fission product deposited on the landscape from weapons-material production plants, and with radioactive products released into the Columbia River from the reactors at Hanford (Stannard 1988). Later, nuclear testing led to the spread of radioactive cesium and strontium isotopes, which prompted research projects on soil migration, root uptake, uptake by grazing and browsing animals, and transfer to food products. A major part of the aquatic research was conducted at Oak Ridge, Hanford, and Savannah River, whereas much of the work on soils, plant uptake, and the dairy pathway was done at agricultural 
schools within major universities. Together, these research efforts pioneered the quantitative study of environmental processes and provided not only the mechanistic

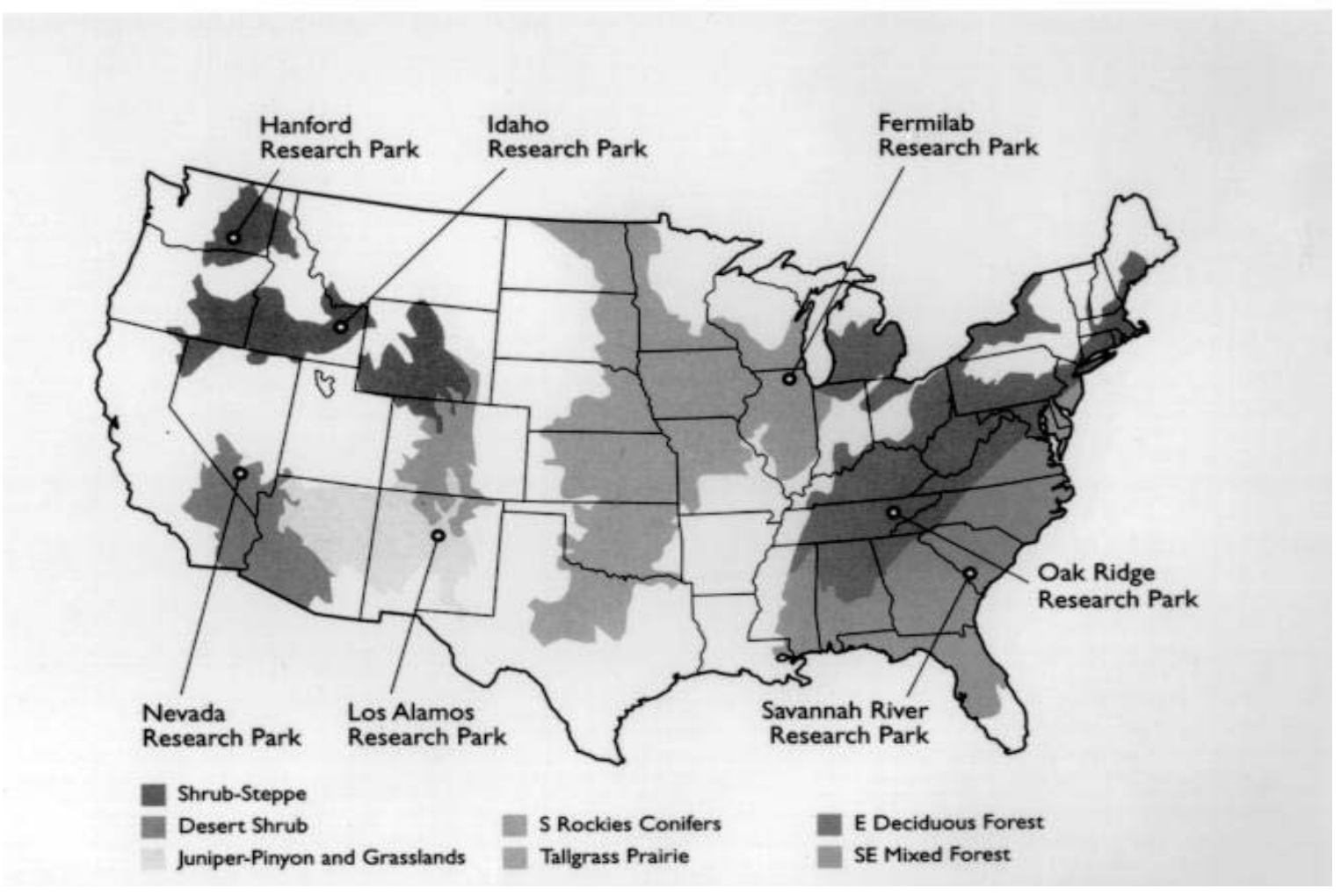

Fig. 2.1. Seven DOE National Environmental Research Parks representing major ecosystems that cover more than half of the lower 48 states. The parks are open to researchers for ecological studies and to the general public for environmental education (DOE 1997). 
understanding, but also the historical databases that supported DOE's early environmental restoration program and that underlie today's ongoing cleanup of contaminated defense sites.

But the first ecological research linked to the nuclear era focused on radioactivity's direct effects - work that predated even the AEC (DOE 1997). Studies by Al Seymour, a fisheries scientist from the University of Washington, were aimed at assessing the possible effects of effluents from Hanford's wartime reactors. And by 1946 the region's sheep and cattle were being monitored for radioactive iodine uptake. Nor was the plant kingdom ignored. For 30 years, starting in 1949, Brookhaven scientists led by Arnold Sparrow studied the effects of radioactivity on plants, first on introduced species and plants of economic importance and later on native species. An important result of this work was the discovery that the volume of the cell nucleus in different plant species was an important factor in determining the species' relative sensitivity to radiation.

In 1950, using phosphorus-32 in a Connecticut lake, Evelyn Hutchinson at Yale documented the quantitative cycling of the element - an essential and often limiting nutrient - within a lake ecosystem. Then, in 1951, the AEC took a major step toward the systematic study of ecology: the agency granted $\$ 10,000$ each to the University of South Carolina and the University of Georgia to conduct a biological inventory of the Savannah River site, in preparation for constructing a facility there to produce materials for nuclear weapons. Eugene Odum led the Georgia effort, in time putting together a research center of international repute, first called the Laboratory of Radiation Ecology, then the Savannah River Ecology Laboratory. Early studies of plant succession and pioneering applications of radiotracers to the study of food chains and food webs led to studies of wetlands ecology, endangered species of the Southeast, regional biodiversity, and the environmental chemistry of trace metals.

Also in the 1950s, the AEC created its Environmental Sciences Branch led by the visionary John Wolfe to support studies of terrestrial, freshwater, and marine systems, with the emphasis on the long-term fate and effects of radionuclides. In this encouraging environment, Stanley Auerbach at Oak Ridge National Laboratory shifted his emphasis from laboratory experiments to field work focused on how radionuclides might migrate through the food chain, from water and soil to plants, animals, and humans. A particular public worry, for example, was strontium-90, which can reach humans via cattle fodder and cow's milk and then accumulate at dangerous levels in bones. As a result of his pioneering fieldwork, Stanley Auerbach would establish the country's leading ecological research program (Auerbach 1993).

Auerbach and his colleagues pursued some of their first studies in the dry bed of White Oak Lake, where Oak Ridge once flushed low-level radioactive wastes. In the course of their studies, Oak Ridge ecologists introduced computer simulations to ecological science, a striking innovation in 1958. Products of this and other AEC research on radionuclide transport and bioaccumulation still provide the basis for models used to assess the impact of radioactive emissions on living organisms, including humans.

In the early 1960s, attention at Oak Ridge shifted to the "cesium forest," a stand of radiolabeled tulip poplars, which produced some of the first research to document the extent to which an element is recycled within a forested ecosystem. Stimulated by earlier assessments of the environmental fate of ${ }^{14} \mathrm{C}$ releases from light water reactors, these 
efforts in 1966 expanded to include ecosystem metabolism. These studies developed the scientific foundation for DOE's later interests in greenhouse gases and terrestrial carbon cycling research and became the centerpiece for the International Biological Program's global woodlands research effort beginning in 1968 (Reichle 1981). Concurrently, ecologists launched the Walker Branch Watershed project, which continues today, one of the two longest-running studies of a forest ecosystem in the United States. Over the years, it has afforded deep insights into the flow of nutrients, water, and contaminants through a forested watershed and on the physical, chemical, and biological processes that control this flow. More broadly, it has provided new tools for evaluating the effects of human activities on natural environments.

The AEC was no less committed to supporting ecological research in universities, where ecologists and limnologists used tracers to study the transport of materials in lakes and rivers, sometimes using entire small lakes as experimental ecosystems. In 1951, for example, Arthur Hasler at the University of Wisconsin took a whole-ecosystem approach in testing a way to manipulate algal and fish production. He separated the two halves of an hourglass-shaped lake in northern Wisconsin with an earthen barrier, thus creating two separate lakes. One was then treated with lime to reduce the acidity and thus the concentration of dark organic matter in the water, while the other remained untreated as a control. In 1960 University of Wisconsin scientists used radiosodium and radioiodine to document the physical and biological mechanisms of material mixing and transport in a chemically stratified lake. Thus, early efforts such as this paved the way for much of modern limnology by offering key insights into how lake ecosystems work and how they might be managed to enhance their intrinsic and utilitarian values.

By the late fifties, thoughtful scientists had become deeply aware of the intricacy and sensitivity of the ecological web. At the same time, proponents of the Plowshare program were proposing to use nuclear detonations to excavate harbors and construct canals. To pave the way for such projects, an experimental harbor excavation, dubbed "Project Chariot," was proposed (Wilmovsky and Wolfe 1966) for northwest Alaska. In a landmark effort, the AEC sent a team of scientists to survey the area beforehand-the first major ecological survey ever done in advance of proposed development. Among the goals were to gather enough information to allow credible estimates of the biological cost of the harbor project and to establish a baseline for assessing future change, natural and otherwise. In the end, the study contributed more basic ecological information about the Arctic than all previous investigations combined. Further, it suggested that Project Chariot would entail unacceptable ecological and public health risks, and, perhaps most important, it presaged a new era of ecological awareness, almost a decade before the National Environmental Policy Act of 1969 would demand such environmental impact assessments.

\subsection{THE LEGACY OF THE 1950s}

DOE's Office of Biological and Environmental Research (OBER) currently supports research in more than 800 research projects at institutions around the country-a research portfolio that, for all its diversity, reflects a direct lineage from the earliest charge to the AEC - to exploit the promise of a new age and to safeguard the public health in the face of its uncertainties (DOE 1997, Stannard 1988). And yet, this constancy of purpose has demanded inevitable change, as new ideas have emerged, as tools have evolved, and as 
the foundation of knowledge has grown. Underscoring this truth is the example of the AEC's interests in biogeochemical cycling and ecosystem metabolism, and DOE's establishment of the National Environmental Research Parks (Figure 2.1) in 1972 as its continuing commitment to ecological research (DOE 1997). Seen in this light, the birth of the global change research program within the Biological and Environmental Research (BER) program is no surprise.

The pioneers of biological and environmental research within the AEC could hardly have predicted the course BER research would take (DOE 1997). Efforts that were focused on the fate of radioactive fallout would evolve into today's global climate research.

Exploratory studies of ecosystem metabolism by means of radiotracers would lead to the first estimates of net ecosystem production and global carbon exchanges by the biosphere. And questions raised by early epidemiological studies would ultimately give rise to the quantification of food chain dynamics and exposure pathways, providing the basis for regulatory standards for radionuclides and hazardous chemicals. The next fifty years are equally unpredictable. The future, as usual, promises unknown challengesand unexpected opportunities. It is certain only that, as technology evolves, so will our responsibilities for understanding the impact of our decisions on human health and the health of our environment. And as long as our well-being depends on the wisdom of our choices, the enduring mandate of the AEC will continue to inform the research of the DOE scientists charged with its legacy. 


\section{REFERENCES}

AEC (Atomic Energy Commission). 1956. Some Effects of Ionizing Radiation on Human Beings. A Report of the Marshallese and Americans Accidentally Exposed to Radiation from Fall-Out and a Discussion of Radiation Injury in the Human Being (eds., E. V. Cronkite, V. P. Bond, and C. L. Dunham). U.S. Government Printing Office, Washington, D.C.

AEC (Atomic Energy Commission). 1961. Atomic Energy Research in the Life and Physical Sciences, 1960. A Special Report of the U.S. Atomic Energy Commission. U.S. Government Printing Office, Washington, D.C.

Auerbach, S. I. 1958. The soil ecosystem and radioactive waste disposal to the ground. Ecology 39(3):522-29.

Auerbach, S. I. 1956. Ecological research. pp 1-17. In Health Physics Division Semiannual Progress Report for Period Ending January 31, 1956. ORNL-2049. Oak Ridge National Laboratory.

Auerbach, S. I. 1965. Radionuclide cycling: Current status and future needs. Health Phys. 11:1355-61.

Auerbach, S. I. 1993. A History of the Environmental Sciences Division of Oak Ridge National Laboratory. ORNL/M-2732. Oak Ridge National Laboratory.

Auerbach, S. I., and J. S. Olson. 1963. Biological and environmental behavior of ruthenium and rhodium. pp.509-519. In V. Schultz and A.W. Klement, Jr. (eds.), Proceedings of the First National Symposium on Radioecology. Reinhold Publishing, New York.

Auerbach, S. I., J. S.Olson, and H. D. Waller. 1964. Landscape investigations using cesium-137. Nature 201(492):761-764.

Auerbach, S. I., D.A. Crossley, Jr., P. B. Dunaway, H. F. Howden, E. R. Graham, K. K. Bohnsack, M. E. Pryor, C. Krauth, and R. M. Anderson. 1958. Ecological research. pp. 27-41. In Health Physics Division Annual Progress Report for Period Ending July 31, 1958. ORNL-2590. Oak Ridge National Laboratory.

Auerbach, S. I., R. M Anderson, D. A. Crossley, Jr., P. B. Dunaway, J. H. Marks, J. S. Olson, V. I. Dodson, M. E. Pryor, and J. P. Witherspoon. 1959. Ecological Research. pp. 18-54. In Health Physics Division Annual Progress Report for Period Ending July 31, 1959. ORNL-2806. Oak Ridge National Laboratory.

Auerbach, S. I., D. A. Crossley, Jr., H. E. Childs, Jr., P. B. Dunaway, S. V. Kaye, G. L. Plummer, J. A. Sealander, R. M. Anderson, U. S. Davis, Jr., V. I. Dodson, L. L. Smith, W. L. Tietjen, and D. C. Walton. 1961. White Oak lake bed studies. pp. 81-139. In Health Physics Division Annual Progress Report for Period Ending July 31, 1961. ORNL-3189. Oak Ridge National Laboratory. 
Bebbington, W. P. 1973. Nuclear Operations and the Environment. DPSPU 72-30-9. E. I. du Pont de Nemours and Company, Atomic Energy Division, Aiken, S.C.

Browder, F. N. (ed.). 1959. Radioactive Waste Management at Oak Ridge National Laboratory. ORNL-2601. Oak Ridge National Laboratory.

Bustad, L. 1960. Radioisotopes and environmental circumstances: Significance of nuclear energy effluents in animal populations. pp. 243-254. In R. S. Caldecott and L. A. Snyder (eds.), Radioisotopes in the Biosphere. University of Minnesota Press, Minneapolis.

Caldecott, R. S., and L. A. Snyder (eds.). 1960. A Symposium on Radioisotopes in the Biosphere. Proceedings of a symposium held in Minneapolis, October 19-23, 1959. University of Minnesota, Minneapolis.

Crossley, D. A., Jr. 1963. Movement and accumulation of radiostrontium and radiocesium in insects. pp. 103-105. In V. Schultz and A. W. Klement, Jr. (eds.), Proceedings of the First National Symposium on Radioecology. Reinhold Publishing, New York.

Crossley, D. A., Jr., and E. F. Howden. 1961. Insect-vegetation relationships in an area contaminated by radioactive wastes. Ecology 42(2):302-317.

DOE (U.S. Department of Energy). 1983. Health and Environmental Research: Summary of Accomplishments. Technical Information Center, DOE.

DOE (U.S. Department of Energy). 1997. A Vital Legacy: Biological and Environmental Research in the Atomic Age (D. Vaughn, ed.). Lawrence Berkeley National Laboratory, Berkeley, Calif.

Eisenbud, M., and J. H. Harley. 1953. Radioactive dust from nuclear detonations. Science 117:141-47.

Foster, R. F. 1972. The history of Hanford and its contribution of radionuclides to the Columbia River. pp. 3-18. In A. T. Pruter and D. L. Alverson (eds.), The Columbia River Estuary and Adjacent Ocean Waters: Bioenvironmental Studies. University of Washington Press, Seattle.

Foster, R. F. 1979. Taped interview. In J. N. Stannard, 1988, Radioactivity and Health: A History. DOE/RL/01830-T59. U.S. Department of Energy. Republished in 1989 by Battelle Press, Columbus, Ohio, in 3 volumes.

Foster, R. F., and J. J. Davis. 1956. The accumulation of radioactive substances in aquatic forms. pp. 364-67. In Proceedings of the International Conference on the Peaceful Uses of Atomic Energy (held in Geneva, August 8-20, 1955), vol. 13. United Nations, New York.

Hanson, W. C. 1963. Iodine in the environment. pp. 581-601. In V. Schultz and A. W. Klement, Jr. (eds.), Proceedings of the First National Symposium on Radiocology. Reinhold Publishing, New York. 
Hanson, W. C., and H. A. Kornberg. 1956. Radioactivity of terrestrial animals near an atomic energy site. pp. 385-388. In Proceedings of the International Conference on the Peaceful Uses of Atomic Energy (held in Geneva, August 8-20, 1955), vol. 13. United Nations, New York.

Johnson, L., and D. Schaffer. 1994. Oak Ridge National Laboratory, The First Fifty Years. The University of Tennessee Press, Knoxville, Tenn.

Kaye, S. V., R. S. Booth, P. S. Rohwer, and E. G. Struxness. 1972. Cumulative exposures index (CUEX) for assessing environmental releases of radioactivity. pp. 909922. In Radioecology Applied to the Protection of Man and His Environment, vols. 1 and 2 (proceedings of a symposium held in Rome, September 7-10, 1971). EUR-4800. European Atomic Energy Community.

Klement, A. W., Jr. (ed.). 1965. Radioactive fallout from nuclear weapons tests. Proceedings of the second conference held at Germantown, MD, November 3-6, 1964. CONF-765. National Technical Information Service, Springfield, Va.

Lee, P. K., and S. I. Auerbach. 1959. Determination and evaluation of the radiation field above White Oak lake bed. ORNL-2755. Oak Ridge National Laboratory.

Morgan, K. Z., and K. M. Peterson. 1999. The Angry Genie: One Man's Walk Through the Nuclear Age. University of Oklahoma Press, Norman, Okla.

Odum, E. P. 1956. Consideration of the total environment in power reactor waste disposal. pp. 350-353. In Proceedings of the International Conference on the Peaceful Uses of Atomic Energy (held in Geneva, August 8-20, 1955), vol. 13. United Nations, New York.

Odum, E. P. 1963. Experimental isolation of food chains in an old-field ecosystem with the uses of phosphorus-32. pp. 113-120. In V. Schultz and A. W. Klement, Jr. (eds.), Proceedings of the First National Symposium on Radiocology. Reinhold Publishing, New York.

Olson, J. S. 1963. Analog computer models for movement of nuclides through ecosystems. pp. 121-125. In V. Schultz and A. W. Klement, Jr. (eds.), Proceedings of the First National Symposium on Radioecology. United Nations, New York.

ORNL (Oak Ridge National Laboratory). 1957. Status Report on the Disposal of Radioactive Wastes. Prepared by the Committee on Disposal and Dispersal of Radioactive Wastes (compiled and edited by F. L. Culler and S. McLain). ORNL 57-3-114. Oak Ridge National Laboratory.

Parker, H. M. 1956. Radiation exposure from environmental hazards. pp. 305-310. In Proceedings of the International Conference on the Peaceful Uses of Atomic Energy (held in Geneva, August 8-20, 1955), vol. 13. United Nations, New York.

Peredel'ski, A. A. 1958. Questions of radioecology. Priroda (Nature) 8-20. 
Randerson, D. (ed.) 1984. Atmospheric Science and Power Production. Office of Scientific and Technical Information, U.S. Department of Energy, Oak Ridge, Tenn.

Reichle, D. E. 1967. Radioisotope turnover and energy flow in terrestrial isopod populations. Ecology 48: 351-66.

Reichle, D. E. 1981. Dynamic Properties of Forest Ecosystems. Cambridge University Press, Cambridge, U.K.

Reichle, D. E., and S. I. Auerbach. 1972. Analysis of ecosystems. pp. 260-280. In J. A. Behnke (ed.), Challenging Biological Problems. Oxford University Press, New York.

Reichle, D. E., and D. A. Crossley, Jr. 1967. Investigation of heterotrophic productivity in forest communities. In K. Petrusewicz (ed.), Principles and Methods of Secondary Productivity of Terrestrial Ecosystems. Panstwowe wydawnictwo naukowe, Warsaw, Poland.

Reichle, D. E., P. B. Dunaway, and D. J. Nelson. 1970. Turnover and concentration of radionuclides in food chains. Nuclear Safety 11: 43-55.

Schultz, V., and A. W. Klement, Jr. (eds). 1963. Radioecology: Proceedings of the First National Symposium on Radioecology (held at Colorado State University, Fort Collins, Colorado, September 10-15, 1961). Reinhold Publishing, New York.

Stannard, J. N. 1988. Radioactivity and Health: A History. DOE/RL/01830-T59. U.S. Department of Energy. Republished in 1989 by Battelle Press, Columbus, Ohio, in 3 volumes.

Tamplin, A. R. 1967. Prediction of the maximum dosage to man from the fallout of nuclear devices. I. Estimation of the maximum contamination of agricultural land. UCRL-50163, pt. I. Lawrence Radiation Laboratory, Livermore, Calif.

Whicker, F. W., and V. Schultz. 1982. Radioecology: Nuclear Energy and the Environment, 2 vol. CRC Press, Inc., Boca Raton, Fla.

Wilmovsky, N. J., and J. N. Wolfe (eds.). 1966. Environment of the Cape Thompson Region, Alaska. U.S. Atomic Energy Commission, Oak Ridge, Tenn.

Witherspoon, J. P. 1963. Cycling of cesium-134 in White Oak trees on sites of contrasting soil type and moisture. pp. 127-132. In V. Schultz and A. W. Klement, Jr. (eds.), Proceedings of the First National Symposium on Radioecology. Reinhold Publishing, New York.

Wolfe, J. N. 1963. Impact of Atomic Energy on Environment and Environmental Science. pp. 1-4. In V. Shultz and A. W. Klement, Jr. (eds.), Proceedings of the First National Symposium on Radioecology. Reinhold Publishing Co., New York. 
ORNL/TM-2003/280

\section{INTERNAL DISTRIBUTION}

1. S. G. Hildebrand, 1505 , MS-6037

2. G. K. Jacobs, 1505 , MS-6037

3. K. Johnson, $4500-\mathrm{N}$, MS-6208

4. M. Z. McLaughlin, 4500-N, MS-6266

\author{
5-6. ESD Library \\ 7. ORNL Central Research Library \\ 8. ORNL Laboratory Records-RC
}

\section{EXTERNAL DISTRIBUTION}

9-13. Stanley Auerbach, 3314 West End Avenue, Apt. 202, Nashville, TN 37203

14. Roger C. Dahlman, Biologist, SC-74, Germantown Building, U.S. Department of Energy, 1000 Independence Ave., S.W., Washington, DC 20585-1290

15. Jerry W. Elwood, Director, Climate Change Research Division, SC-74, Germantown Building, U.S. Department of Energy, 1000 Independence Ave., S.W., Washington, DC 20585-1290

16. Aristides A. Patrinos, Associate Director for Biological and Environmental Research, SC-70, Germantown Building, U.S. Department of Energy, 1000 Independence Ave., S.W., Washington, DC 20585-1290

17-21. David Reichle, 237 Mainsail Road, Kingston, TN 37763

22. Murray Schulman, 215 Summit Hall Road, Gaithersburg, MD 20877

23. Steve Stow, American Museum of Science and Energy, 300 S. Tulane Avenue, Oak Ridge, TN 37830

24. Ward F. Whicker, Department of Molecular and Radiological Sciences, 335 Molecular and Radiological Biosciences Bldg., 1618 Campus Delivery, Colorado State University, Fort Collins, CO 80523-1020 
